'ORTO RICO AGRICULTURAL EXPERIMENT STATION, D. W. MAY, Special Agent in Charge.

Mayaguez, May, rgir.

Bulletin No. 11.

\title{
RELATION OF CALCAREOUS SOILS TO PINEAṔPLE CHLOROSIS.
}

BY

P. L. GILE, CHEMIST.

UNDER THE SUPERVISION OF OFFICE OF EXPERIMENT STATIONS,

U. S. DEPARTMENT OF AGRICULTURE.

WASHINGTON:

GOVERNMENT PRINTING OFFIOE.

1911. 




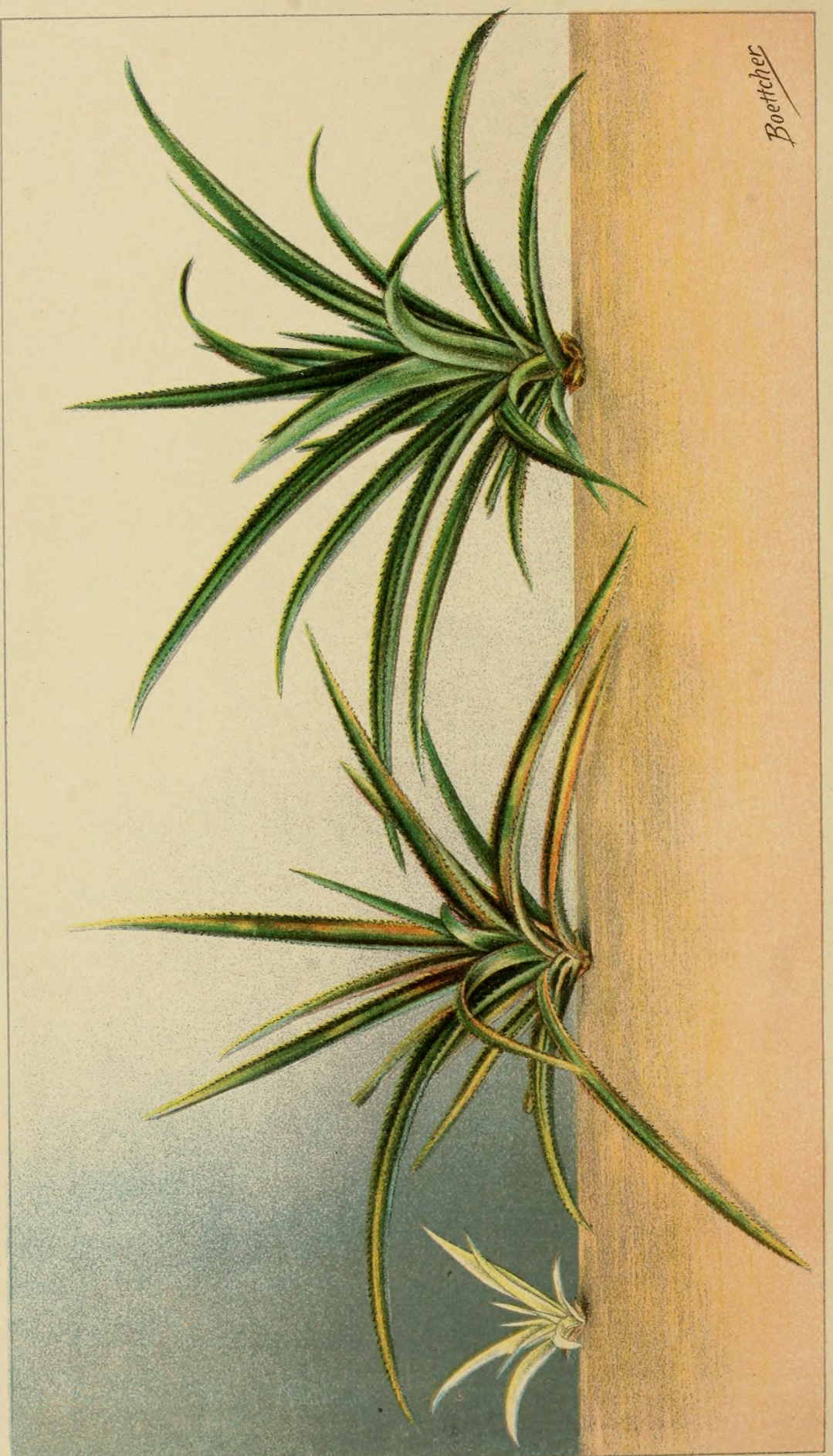

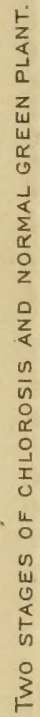


PORT0 RICO AGRICULTURAL EXPERIMENT STATION, I

D. W. MAY, Special Agent in Charge.

Mayaguez, May, IgrI.

Bulletin No. 11.

\title{
RELATIION OF CALCAREOUS SOILS TO PINEAPPLE CHLOROSIS.
}

BY

\author{
P. L. GILE, \\ CHEMIST
}

UNDER THE SUPERVISION OF

OFFICE OF EXPERLMENT STATIONS,

U. S. DEPARTMENT OF AGRICULTURE,

WASHINGTON :

GOVERNMENT PRINTING OFFICE,

1911.

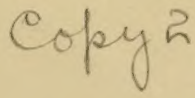




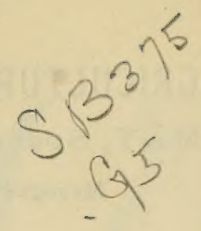

PORTO RICO AGRICULTURAL EXPERIMENT STATION.

[Under the supervision of A. C. True, Director of the Office of Experiment Stations, United States Department of Agriculture.]

Walter H. Evans,

Chief of Division of Insular Stations, Office of Experiment Stations.

STATION STAFF.

D. W. May, Special Agent in Charge.

Oscar Loew, Physiologist.

W. V. Tower, Entomologist.

P. L. GILE, Chemist.

G. L. Fawcett, Plant Pathologist.

C. F. Kinman, Horticulturist.

E. G. Ritzman, Animal Husbandman.

T. B. McClelland, Assistant Horticulturist.

C. N. Ageton, Assistant Chemist.

W. E. Hess, Expert Gardener.

Carmelo Alemar, Jr., Stenographer. 


\section{LETTER OF TRANSMITTAL.}

Porto Rico Agricultural Experiment Station, Mayaguez, Porto Rico, May 1, 1911.

SIR: I have the honor to transmit herewith a manuscript on the subject of Relation of Calcareous Soils to Pineapple Chlorosis. Owing to the great increase in importance of this fruit in Porto Rico any investigation leading to its improvement is timely. The number of failures occurring in certain soils which apparently are well adapted to pineapple growing lends value to the results as set forth in this manuscript, which offers an explanation of the cause of the failures and suggests means of avoiding great losses in the future.

I respectfully recommend that this manuscript be issued as Bulletin No. 11 of this station and that it be published in both English and Spanish.

Respectfully,

$$
\begin{gathered}
\text { D. W. MAY, } \\
\text { Special Agent in Charge. }
\end{gathered}
$$

Dr. A. C. True,

Director Office of Experiment Stations,

U. S. Department of Agriculture, Washington, D.C.

Recommended for publication.
A. C. True, Director.

Publication authorized.

JAMES WILSON,

Secretary of Agriculture

[Bull. 11] 


\section{CONTENTS.}

Page.

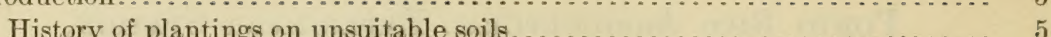

History of plantings on unsuitable soils ......................... 5

A ppearance of plants on unsuitable soils. . . . . . . . . . . . . 6

Preliminary investigations. ............................... 6

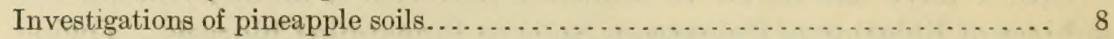

Chemical survey of the pineapple soils of Porto Rico............... 8

Pineapple soils of other countries.......................... 18

Pot experiments with different types of soil . . . . . . . . . . . . . . . 20

Experiments with plants grown in small field plats. . . . . . . . . . . . . 26

Conclusions from soil investigations. . . . . . . . . . . . . . . . . . 27

Investigations of the chlorosis . . . . . . . . . . . . . . . . . . . . . . . .

Previous work on lime-induced chlorosis. . . . . . . . . . . . . . . . . . . 29

Effect of soil alkalinity and assimilable lime in causing chlorosis . . . . . . . 31

Treatment of chlorotic plants with iron and other salts . . . . . . . . . . . . . . 32

Ash content of green and chlorotic leaves. . . . . . . . . . . . . . . . . . . . 34

Enzyms in chlorotic and green leaves............................ 39

Effect of light on the chlorosis............................. 42

Conclusions from investigations of the chlorosis . . . . . . . . . . . . . 43

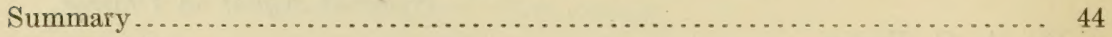

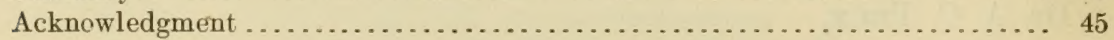

\section{IL L U S T R A T I O N S.}

Plate I. Normal green plant and two stages of chlorosis ........... Frontispiece.

II. Fig. 1.-Effect of carbonate of lime on the growth of pineapples.

Fig. 2.-Effect of ferrous sulphate on chlorotic pineapple plants.... 22

[Bull. 11]

(4) 


\section{RELATION OF CALCAREOUS SOILS TO PINEAPPLE CHLOROSIS.}

\section{INTRODUCTION.}

\section{HISTORY OF PLANTINGS ON UNSUITABLE SOILS.}

Raising pineapples on a commercial scale is a comparatively new but rapidly growing industry in Porto Rico. As more and more land is being planted to pineapples it is becoming apparent that all of the loose, well-drained soils are not adapted to this crop. On certain well-drained soils of good physical condition the pineapple plantings have been very unsuccessful. The failure of these plantings has been attended by a peculiar "bleaching" or chlorosis ${ }^{1}$ of the plants, in some cases so complete that the leaves contain hardly a trace of chlorophyll.

The investigation detailed in the following pages was undertaken for the purpose of discovering the cause of the chlorosis and the failure of the crop on these soils.

The first instance of the plants presenting this peculiar bleached appearance on a well-drained soil was noted at Rincon, P. R., by Mr. H. C. Henricksen in 1904, and is described in the annual report of this station for $1905:^{2}$

In the fall of 1903 about 2 acres were planted at Rincon with the variety Cabezona. The plants were reported to be diseased and the field was visited April, 1904, at the owner's request. The plants were found to be of normal size, but the color of the leaves was of a light red to pure wax white, about 50 per cent being entirely devoid of chlorophyll and less than 15 per cent showing green, the rest red, green, and white mixed. The field was located near the ocean, but in no way injured by salt water. The soil, which was a beach sand, had recently been cleared of its natural growth, consisting mainly of coconut, sea grape, coco plum, a few sour orange trees, and the usual tropical shore-line plants.

Since this case was reported numerous other instances of pineapples showing the same appearance have been noted. On two plantations, of about 10 acres each, the plants became almost uniformily yellowish white and ultimately succumbed. About 60 per

1 Chlorosis (sometimes called "icterus," "bleaching," or "Gelbsucht") is the term applied to that condition assumed by the leaves of plants when they fail to develop the normal amount of chlorophyll, or green coloring matter, i. e., when they are yellowish or white instead of a normal green. Chlorosis, then, does not denote a specific disease, but merely a general condition. This condition of chlorosis, however, is the result or outward sign of a disease or disturbance in the physiology of the plant. To say that a plant is "chlorotic," or affected with chlorosis, means merely that its leaves are lacking in chlorophyll; but the ehlorosis may have resulted from a bacterial disease, poor drainage, lack of nutriment, or some other cause.

2 Porto Rico Sta. Rpt. 1905, p. 30.

[Bull. 11] 
cent of the plants in another 10-acre field are now affected the same way. Several fields of 1 or 2 acres with the same symptoms have been lost, and numerous cases of a few hundred plants showing this peculiar chlorosis have been observed in different plantations.

The places where the chlorotic plants occurred were not confined to any one district of the island or to any one physical type of soil.

\section{APPEARANCE OF PLANTS ON UNSUITABLE SOILS.}

The degree to which the plants were affected and the age of the plants when the bleaching first manifested itself varied somewhat in the different instances. In some places many plants became almost ivory white, apparently without a vestige of chlorophyll; later the leaves of such plants showed brown spots and the plants finally decayed. In other cases the leaves were a yellowish white, with red streaks and small patches of green. Sometimes the outer leaves remained a light green while the new heart leaves were creamy white. In other cases the leaves were for many months practically normal in color, but gradually light spots appeared, producing a mottled appearance, and finally, in 14 or 15 months, the leaves bleached out to a uniform greenish yellow. The lack of chlorophyll, or chlorosis, was generally very pronounced when the plant was 9 months old, though sometimes it appeared in 3 or 4 months, and sometimes it did not appear until the plant was 15 or 16 months old.

The root system of the chlorotic plants showed no evidence of disease. The roots differed from those of normal plants in being somewhat longer and not so thick; they were more like those of plants suffering from starvation. The plants, however, that had suffered from the chlorosis for some time had many dead roots, but the functioning roots appeared to be perfectly healthy and on examination by the pathologist failed to show any bacterial or fungus trouble.

\section{PRELIMINARY INVESTIGATIONS.}

From the fact that the first examples of the chlorosis appeared in plantations near the sea it was thought by some that the trouble was caused by sea spray being blown in on the plants. This was shown not to be the case, however, as on some plantations within less than a hundred yards of the sea the plants were perfectly green and healthy and later the distinctive chlorosis was observed on plantations several miles from the coast; moreover, plants heavily sprayed with sea water for four consecutive days showed no injury.

It was also thought that the chlorosis might be attributed to lack of aeration of the roots from poor drainage. In some places where the chlorosis occurred the drainage was poor, and in the spots of poorest drainage the chloriosis was most intense. In other places, however, 
plants on loose, sandy soils of perfect drainage became strongly chlorotic. It was thus apparent that although the trouble was intensified by poor drainage, faulty drainage was not the primary cause.

The appearance of patches of chlorotic plants in the midst of fields that were for the most part green and vigorous made it seem probable that it was a bacterial disease. But investigations by the pathologist failed to reveal any bacterial or fungus disease. The fact that chlorotic plants on transplanting to different soils in every case recovered also militated against this view. Chlorotic plants and soil were secured from three different plantations and placed in pots. The chlorotic plants in the original soil in all cases remained without change, while those placed in a river sand became, in a short time, green and healthy. Also, since these investigations were started 6 acres of chlorotic plants have been taken up and set out in soil of a different character. Iere they became green within a month or two, and, in the year that has elapsed since transplanting, not a single plant has developed the chlorosis. Had the plants been infested with bacteria or fungi they could hardly have shown such a uniform recovery on transplanting to different soils of a similar physical character.

Experiments with commercial fertilizers and stable manure were tried in 1904 and 1908 by the horticulturist on two of the plantations, where the chlorosis was very marked, to see whether the trouble could have been caused by lack of nutriment.

It was found that although the complete fertilizers improved the condition of the plants slightly, they were without much effect. The stable manure produced slightly more improvement than the commercial fertilizers.

It being, then, seemingly impossible that the chlorosis could have been produced by disease, lack of nutriment, poor drainage, or injury from the sea, it was thought probable that the cause was to be found in the unsuitable chemical character of the soil. Accordingly, soils were collected from all the areas where the chlorosis occurred and from adjacent fields where the pineapples were doing well. In some cases patches of a few hundred chlorotic plants occurred in the midst of several acres of healthy green plants. Hence, it was to be expected that, if the trouble was due to the chemical character of the soil, a difference would be apparent in the analyses of the soils where the healthy and unhealthy plants were growing. In addition to such comparative analyses, analyses were made of most of the well-drained soils where pineapples were growing well. It was thought that, should the soils producing chlorotic plants show a chemical character that adjacent areas with healthy plants did not, and should none of the good pineapple soils show the same characteristics as the bleached areas, the specific cause would become apparent.

[Bull. 11] 
INVESTIGATIONS OF PINEAPPLE SOILS.

CHEMICAL SURVEY OF THE PINEAPPLE SOILS OF PORTO RICO.

The individual cases where chlorotic pineapples were found are described below. The analysis of the soil is given in each case, together with that of adjacent areas where pineapples grow well.

The samples were all taken from the first 8 inches of soil, as in this part of the soil practically all the pineapple roots are found. The analyses were made by digestion with hydrochloric acid of specific gravity 1.115 according to the official methods of the Association of Official Agricultural Chemists. The carbon dioxid was determined by absorption and from this the percentage of calcium carbonate calculated. This does not give a strictly accurate determination of the lime present as carbonate, inasmuch as it fails to distinguish between calcium and magnesium carbonate. For the purpose, however, the method suffices. The oxids of lime and magnesia were of course exactly determined in the acid digestion.

All of the following samples were tested for water soluble alkaline salts and chlorids, but none was found present. The alkaline reaction of certain of the soils is due to the presence of the carbonates of lime and magnesium.

SOIL SURVEY I.

Plantation (Isla Verde) of Mr. Noble, about 5 miles east of Santurce, P. R.: Here there were 10 acres of Red Spanish pineapples on a loose, well-drained, gray sand, a few hundred yards from the sea. The surrounding vegetation consisted of icacos, Santa Maria, roble, and leguminous weeds and low growing bushes. In 9 or 10 months the plants had all become chlorotic with the exception of a 2-acre patch at one corner of the field and a few scattered individuals. The few isolated plants later lost their color, while in the 2-acre patch they did not lose their green color up to the time of fruiting and produced fruit of sizes 18,24 , and 36 at the rate of 300 boxes per acre. The plants were fertilized at various times with a complete pineapple fertilizer.

A year after planting, about 6 acres of chlorotic plants were taken up and set out in a field a quarter of a mile farther inland on a reddish sandy soil, of finer texture than that of the original field. The plants soon recovered their normal green color and have continued to grow well without showing any chlorosis.

Below are given the soil analyses. Samples 101 and 102 were taken from patches where the plants became chlorotic; No. 79 is the subsoil beneath chlorotic plants; No. 132 is from the corner of the field where the chlorosis failed to appear; No. 152 is a sample from the field to which the plants were transplanted with a complete recovery.

[Bull. 11] 
Analyses of pineapple soils.

\begin{tabular}{|c|c|c|c|c|c|}
\hline Soil constituents and reactions. & $\begin{array}{c}\text { No. } 79 . \\
\text { (plants } \\
\text { chlorotic). }\end{array}$ & $\begin{array}{l}\text { No. } 101 . \\
\text { (plants } \\
\text { chlorotic). }\end{array}$ & $\begin{array}{l}\text { No. } 102 . \\
\text { (plants } \\
\text { chlorotic). }\end{array}$ & $\begin{array}{l}\text { No. } 132 . \\
\text { (plants } \\
\text { healthy). }\end{array}$ & $\begin{array}{c}\text { No. } 152 . \\
\text { (plants } \\
\text { healthy). }\end{array}$ \\
\hline 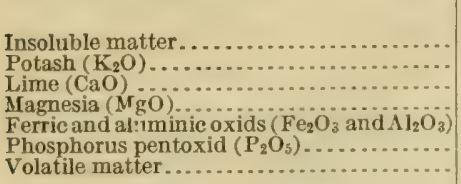 & $\begin{array}{r}\text { Per cent. } \\
54.04 \\
.06 \\
22.27 \\
2.01 \\
.79 \\
.04 \\
20.79\end{array}$ & $\begin{array}{r}\text { Per cent. } \\
56.85 \\
.03 \\
20.40 \\
.78 \\
2.06 \\
.05 \\
19.87\end{array}$ & $\begin{array}{r}\text { Per cent. } \\
56.69 \\
.03 \\
19.54 \\
.86 \\
2.12 \\
.06 \\
21.23\end{array}$ & 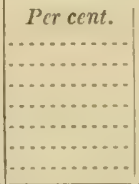 & $\begin{array}{r}\text { Per cent. } \\
89.76 \\
.08 \\
.15 \\
.77 \\
5.70 \\
.03 \\
3.16\end{array}$ \\
\hline Total.... & 100.00 & 100.04 & 100.53 & $\cdots$ & 99.65 \\
\hline $\begin{array}{l}\text { Nitrogen }(\mathrm{N}) \\
\text { Moisture } \\
\text { Carbon dioxid }\left(\mathrm{CO}_{2}\right) \ldots \ldots \ldots \\
\text { Calcium carbonate }\left(\mathrm{CaCO}{ }_{3}\right) \ldots \ldots \ldots \ldots \ldots \\
\text { Reaction to litmus } \ldots \ldots \ldots \ldots \ldots \ldots\end{array}$ & $\begin{array}{r}.02 \\
1.37 \\
\text { Alkaline. }\end{array}$ & $\begin{array}{r}4.12 \\
14.81 \\
33.85 \\
\text { Alkaline. }\end{array}$ & $\begin{array}{r}4.42 \\
14.14 \\
32.17 \\
\text { Alkalinc. }\end{array}$ & $\begin{array}{r}\text { Trace. } \\
\text { Trace. } \\
\text { Alkaline. }\end{array}$ & $\begin{array}{r}.06 \\
.43 \\
\text { Trace. } \\
\text { Trace. } \\
\text { Neutral. }\end{array}$ \\
\hline
\end{tabular}

It will be seen by the above analyses that the soils where the plants became chlorotic contain a large amount of carbonate of lime, that the soil where the plants remained healthy contains a trace, and that the soil where the chlorotic plants recovered contains but little lime and no carbonate of lime.

\section{SOIL SURVEY II.}

Plantation of the Bird Bros, at Luquillo: This planting of Red Spanish pineapples consisted of about 10 acres or more; it was on a loose sandy soil a few hundred yards from the sea. The pineapples were planted between coconut trees. The soil was of good physical condition, but the land was so low that the drainage was poor. After very heavy rains the water was found standing within 12 inches of the surface.

The chlorosis here was more marked than on any other plantation. When 6 or 8 months old most of the plants were waxy white. At the end of 18 months many plants were dead, the greater part of the remainder were colorless, while a few were of a light green with long spiky leaves. About a dozen plants with very small fruits were found. On no part of this field were the plants vigorous. The analyses of samples of soil taken from various parts of the planting are given below:

Analyses of pineapple soils (plants chlorotic).

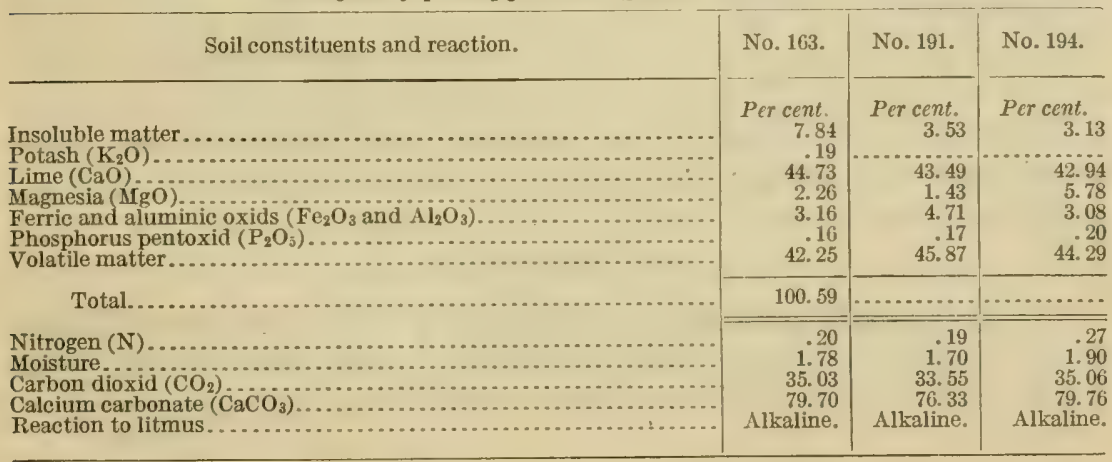

$412^{\circ}-$ Bull. $11-11-2$ 
This is a coralline sand, evidently formed by the sea grinding down coral reefs. It will be seen that although it is fairly rich in nitrogen, potash, and phosphoric acid it is excessively calcareous, like the bad soils in Survey I. The trouble here, however, was complicated by poor drainage.

\section{SOIL SURVEY III.}

Plantation of Mr. Mathews at Rincon, P. R.: This is the plantation described on page 5. In 1910 the field was visited by the writer. The plants had been removed some years previous, but a few plants were found which were of fair size, although practically colorless. A soil sample, No. 224, was taken near these plants.

In the ricinity 6 or 7 plants of the native variety Caraqueña were found growing. Two of these plants were very small and almost pure white; the others were of fair size with very light green narrow leaves. The soil sample from near the roots of these plants is No. 225.

A quarter of a mile farther on a small patch of about a hundred Cabezonas and Caraqueñas were found growing. All the plants were of small size and light-greenish yellow or yellow-white in color. A few plants were bearing dwarfed fruits. The soil from this spot is designated as No. 226. The soil in these three cases was of the same character, a coarse, well-drained, beach sand with a fair amount of organic matter. Coconuts, oranges, and gandules or pigeon peas seemed to grow well here.

Analyses of pineapple soils (plants chlorotic).

\begin{tabular}{|c|c|c|c|}
\hline Soil constituents and reaction. & No. 224. & No. 225 . & No. 226. \\
\hline 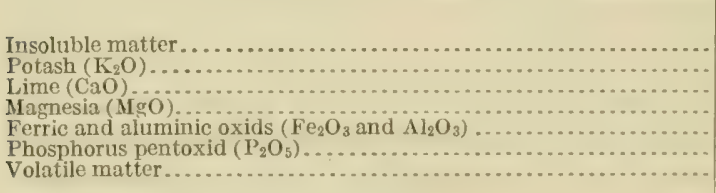 & $\begin{array}{r}\text { Per cent. } \\
70.15 \\
.09 \\
11.77 \\
.36 \\
4.06 \\
.09 \\
12.95\end{array}$ & $\begin{array}{r}\text { Per cent. } \\
67.63 \\
.09 \\
12.40 \\
1.07 \\
4.52 \\
13.16 \\
13.29\end{array}$ & $\begin{array}{r}\text { Percent. } \\
75.36 \\
.09 \\
8.28 \\
5.20 \\
5.20 \\
.12 \\
10.80\end{array}$ \\
\hline Total & 99.47 & 99.16 & 100.12 \\
\hline 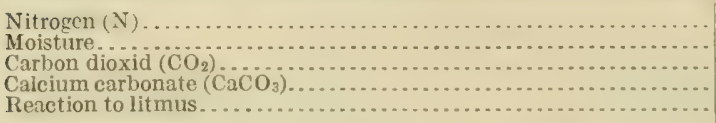 & $\begin{array}{r}.09 \\
7.99 \\
18.04 \\
\text { Alkaline. }\end{array}$ & $\begin{array}{r}.10 \\
.76 \\
9.57 \\
21.77 \\
\text { Alkaline. }\end{array}$ & $\begin{array}{r}.16 \\
1.00 \\
6.29 \\
14.31 \\
\text { Alkaline. }\end{array}$ \\
\hline
\end{tabular}

These soils are slightly richer in potash and phosphoric acid than in Survey I and not so high in lime, but they are still to be regarded as strongly calcareous.

SOIL SURVEY IV.

Property of Mr. William Gay, Dorado, P. R.: Here about 2 acres of red Spanish pineapples were set out on a sand near the sea. The soil was of good physical character with considerable organic matter,

[Bull. 11] 
but so low that during heavy rains the ground water approached the surface. Most of the plants did fairly well, but a strip about 10 yards wide, running transversely across the field, exhibited the characteristic chlorosis, having ivory white leaves with small patches of green. The field had been fertilized with stable manure. Citrus fruits and gandules grew exceptionally well on this plantation. Sample 148 is of the soil where the pineapples were healthy, and 149 is from a patch of chlorotic plants. These samples were taken by one of the station staff. Sample 154 is another sample of the bad soil and 155 of the good soil sent in by Mr. Gay. The samples of good and bad soil were taken only a few yards apart.

Analyses of pineapple soils.

\begin{tabular}{|c|c|c|c|c|}
\hline Soil constituents and reaction. & $\begin{array}{c}\text { No. } 148 \\
\text { (plants } \\
\text { healthy). }\end{array}$ & $\begin{array}{l}\text { No. } 149 \\
\text { (plants } \\
\text { chlorotic). }\end{array}$ & $\begin{array}{l}\text { No. } 154 \\
\text { (plants } \\
\text { chlorotic). }\end{array}$ & $\begin{array}{c}\text { No. } 155 \\
\text { (plants } \\
\text { healthy). }\end{array}$ \\
\hline 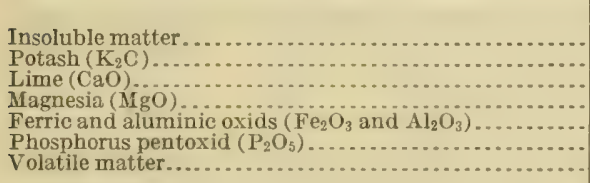 & $\begin{array}{r}\text { Per cent. } \\
93.28 \\
.07 \\
1.92 \\
.14 \\
.51 \\
.04 \\
4.12\end{array}$ & $\begin{array}{r}\text { Per cent. } \\
44.02 \\
.04 \\
22.19 \\
2.50 \\
2.31 \\
.09 \\
27.84\end{array}$ & $\begin{array}{r}\text { Per cent. } \\
63.19 \\
1.32 \\
16.02 \\
1.58 \\
1.59 \\
18.07\end{array}$ & $\begin{array}{r}\text { Per cent. } \\
93.17 \\
.22 \\
1.00 \\
.37 \\
.91 \\
.02 \\
3.51\end{array}$ \\
\hline Tota & 100.08 & 98.99 & 100.93 & 99.20 \\
\hline $\begin{array}{l}\text { Nitrogen (N) } \\
\text { Moisture } \\
\text { Carbon dioxid }\left(\mathrm{CO}_{2}\right) \\
\text { Calcium carbonate }\left(\mathrm{CaCO}_{3}\right) \\
\text { Reaction to litmus....... }\end{array}$ & $\begin{array}{r}.08 \\
.58 \\
.50 \\
1.14 \\
\text { Alkaline. }\end{array}$ & $\begin{array}{r}.30 \\
.27 \\
16.96 \\
38.56 \\
\text { Alkaline. }\end{array}$ & $\begin{array}{r}.22 \\
3.30 \\
10.69 \\
24.32 \\
\text { Alkaline. }\end{array}$ & $\begin{array}{r}.11 \\
1.07 \\
.09 \\
.20 \\
\text { Alkaline. }\end{array}$ \\
\hline
\end{tabular}

It will be seen that 149 is, on the whole, richer in plant food than 148 but that the bad soil is here again strongly calcareous while the good soil has but little calcium carbonate. The same difference is true of 154 and 155 . The calcium carbonate in the bad soil plainly originated from disintegrated coral.

SOIL SURVEY V.

Property of Mr. Pizá, Dorado, P. R.: This plantation consisted of about 30 acres of red Spanish pineapples. The greater part of the plants were on a white, almost pure silica sand; the rest of the plants were on a red clay of varying stiffness. Only two patches of chlorotic plants were found. These were growing in a fairly stiff loam on a hill near the seashore. In one spot there were three small plants almost ivory white in color. These were surrounded by large vigorous plants of a dark-green color. Sample 197 is taken from about the roots of the white plants. The soil here, however, was only 3 inches deep, and the roots of the plants were directly on the surface of the coral rock; there were numerous coral nodules in the

[Bull. 11] 
soil. Sample 198 was taken from a patch of exceptionally vigorous plants 10 yards away. About 100 yards distant was another patch of 50 colorless plants. The soil, of which No. 199 is a sample, contained many coral particles but was over 2 feet deep. No. 200 was taken from the midst of vigorous plants 15 yards distant from No. 199. The soil here contained no coral particles. Twenty-five per cent of sample 197, 4 per cent of 198, and 40 per cent of 199 did not pass through a 1 millimeter sieve. This residue that is not included in the analyses was made up of coral particles, i. e., calcium carbonate. Hence the soil in these three cases must be regarded as containing more calcium carbonate than appears in the analyses.

Analyses of pineapple soils.

\begin{tabular}{|c|c|c|c|c|}
\hline Soil constituents and reaction. & $\begin{array}{c}\text { No. } 197 \\
\text { (plants } \\
\text { chlorotic). }\end{array}$ & $\begin{array}{r}\text { No. } 198 \\
\text { (plants } \\
\text { healthy). }\end{array}$ & $\begin{array}{c}\text { No. } 199 \\
\text { (plants } \\
\text { chlorotic). }\end{array}$ & $\begin{array}{c}\text { No. } 200 \\
\text { (plants } \\
\text { healthy). }\end{array}$ \\
\hline 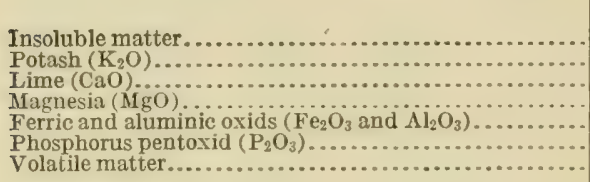 & $\begin{array}{r}\text { Per cent. } \\
73.91 \\
.20 \\
5.17 \\
\text { Trace. } \\
9.24 \\
1.13 \\
11.65\end{array}$ & $\begin{array}{r}\text { Pcr cent. } \\
83.08 \\
.24 \\
1.44 \\
.42 \\
6.03 \\
.09 \\
8.71\end{array}$ & $\begin{array}{r}\text { Per cent. } \\
79.43 \\
.24 \\
3.41 \\
.35 \\
6.66 \\
.08 \\
8.93\end{array}$ & $\begin{array}{r}\text { Per cent. } \\
81.74 \\
.24 \\
1.50 \\
. .25 \\
9.61 \\
.08 \\
6.50\end{array}$ \\
\hline Total. & 100.30 & 100. 01 & 99.13 & 99.92 \\
\hline 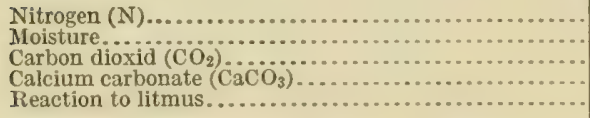 & 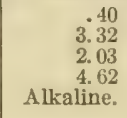 & $\begin{array}{r}4.10 \\
.00 \\
.00 \\
\text { Alkaline. }\end{array}$ & $\begin{array}{r}\text { 3. } 22 \\
2.22 \\
\text { 5. } 05 \\
\text { Alkaline. }\end{array}$ & $\begin{array}{r}.18 \\
\text { Trace. } \\
\text { Trace. } \\
\text { Alkaline. }\end{array}$ \\
\hline
\end{tabular}

Here again the difference between the good and bad soils, lying in such close proximity to each other, is in the content of calcium carbonate.

SOIL SURVEY VI.

Plantation of Arturo S. Jimenez (Plantage del Rio) about 3 miles west of Bayamon: Of about 2 acres of red Spanish pineapples planted here 90 per cent had lost their color within 12 months. Six months later the remaining 10 per cent became colorless and the plants were removed. The planting was located a mile or more distant from the sea on a loose, sandy soil that contained many shell particles, Bananas and native corn were growing fairly well here. Previous to planting with pineapples a good crop of tobacco had been taken from this field. Samples 183 and 185 were taken from two different parts of the field by the writer; No. 156, from the same field, was taken by a neighboring planter. No. 157 is a sample from a nearby healthy planting and was taken by the owner.

[Bull, 11] 
Analyses of pineapple soils.

\begin{tabular}{|c|c|c|c|c|}
\hline Soil constituents and reaction. & $\begin{array}{c}\text { No. } 183 \\
\text { (plants } \\
\text { chlorotic). }\end{array}$ & $\begin{array}{c}\text { No. } 185 \\
\text { (plants } \\
\text { chlorotic). }\end{array}$ & $\begin{array}{c}\text { No. } 156 \\
\text { (plants } \\
\text { chlorotic). }\end{array}$ & $\begin{array}{c}\text { No. } 157 \\
\text { (plants } \\
\text { healthy). }\end{array}$ \\
\hline 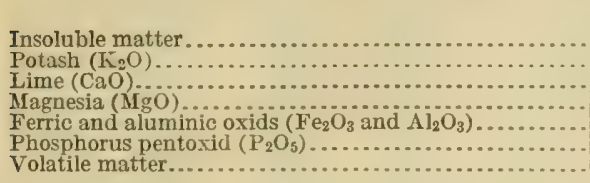 & $\begin{array}{r}\text { Per cent. } \\
70.26 \\
.13 \\
10.47 \\
.74 \\
7.58 \\
11.18 \\
11.35\end{array}$ & $\begin{array}{r}\text { Per cent. } \\
73.07 \\
.12 \\
8.27 \\
1.12 \\
7.42 \\
.21 \\
10.18\end{array}$ & $\begin{array}{r}\text { Per cent. } \\
67.15 \\
11.42 \\
1.17 \\
9.57 \\
.07 \\
12.41\end{array}$ & $\begin{array}{r}\text { Percent. } \\
82.13 \\
.10 \\
2.01 \\
.21 \\
8.77 \\
.29 \\
7.33\end{array}$ \\
\hline Tota & 100.71 & 100.39 & & 100. \\
\hline 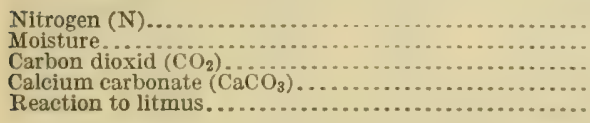 & $\begin{array}{r}.11 \\
4.60 \\
7.15 \\
16.27 \\
\text { Alkaline. }\end{array}$ & $\begin{array}{r}.11 \\
1.89 \\
5.18 \\
11.78 \\
\text { Alkaline. }\end{array}$ & $\begin{array}{r}.16 \\
1.95 \\
6.66 \\
15.15 \\
\text { Alkaline. }\end{array}$ & $\begin{array}{r}5.21 \\
5.44 \\
\text { None. } \\
\text { None. } \\
\text { Alkaline. }\end{array}$ \\
\hline
\end{tabular}

The three soils producing chlorotic plants are very similar to the soils in Survey III and are strongly calcareous, while the good soil (No. 157) differs only in containing no calcium carbonate.

\section{SOIL SURVEY VII.}

Plantation of Golden Fruit Co., about 3 miles from Bayamón: At various times about 40 acres were planted with Red Spanish pineapples. About half the acreage produced remarkably large plants that bore a good crop of large-sized fruit. Most of the plants were fertilized with a complete commercial fertilizer and a few received some barnyard manure. The soil of these fields was a loose, loamy sand with considerable organic matter and is represented by samples 186 and 187.

Another field of about 20 acres was planted in the fall of 1909 . A year later about 50 per cent of the plants had lost most of their green color and many had died. The 50 per cent that were unaffected were of normal dark green and were distributed in irregular patches throughout the field. The soil in this case was a loose sand that in spots contained many shell particles. Sample 229 was taken from a patch of colorless plants and 230 from an area a few yards distant, where the plants were green. It was observed that wherever in the field the soil contained many shell particles the plants were chlorotic and where these particles were absent the plants were green. The soil also was tested in many places with acid, and wherever the chlorotic plants were found the effervescence showed the presence of carbonate of lime, while wherever the green plants were found there was no efiervescence.

[Bull. 11] 
Analyses of pineapple soils.

\begin{tabular}{|c|c|c|c|c|c|}
\hline Soil constituents and reaction. & $\begin{array}{c}\text { No. } 231 \\
\text { (plants } \\
\text { chlorotic). }\end{array}$ & $\begin{array}{c}\text { No. } 186 \\
\text { (plants } \\
\text { healthy). }\end{array}$ & $\begin{array}{c}\text { No. } 187 \\
\text { (plants } \\
\text { healthy). }\end{array}$ & $\begin{array}{c}\text { No. } 229 \\
\text { (plants } \\
\text { chilorotic). }\end{array}$ & $\begin{array}{c}\text { No. } 230 \\
\text { (plants } \\
\text { healthy). }\end{array}$ \\
\hline 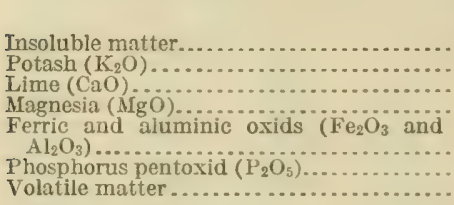 & $\begin{array}{r}\text { Per cent. } \\
79.54 \\
2.45 \\
\text { Trace. } \\
9.20 \\
.17 \\
7.85\end{array}$ & $\begin{array}{r}\text { Per cent. } \\
79.01 \\
.12 \\
4.25 \\
.17 \\
9.50 \\
7.12 \\
7.42\end{array}$ & $\begin{array}{r}\text { Per cent. } \\
83.37 \\
.10 \\
.97 \\
\text { Trace. } \\
7.44 \\
7.09\end{array}$ & $\begin{array}{r}\text { Per cent. } \\
80.97 \\
.16 \\
3.57 \\
.77 \\
8.24 \\
.11 \\
6.53\end{array}$ & $\begin{array}{r}\text { Per cent. } \\
81.12 \\
.17 \\
1.36 \\
\text { Trace. } \\
11.56 \\
.13 \\
6.48\end{array}$ \\
\hline Tota & . & 100.59 & 99.16 & 100.35 & 100.82 \\
\hline 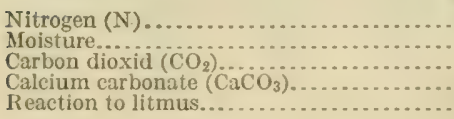 & $\begin{array}{r}2.30 \\
.82 \\
1.86 \\
\text { Alkaline. }\end{array}$ & $\begin{array}{r}.20 \\
1.93 \\
.24 \\
.57 \\
\text { Alkaline. }\end{array}$ & $\begin{array}{r}5.20 \\
.00 \\
.00 \\
\text { Alkaline. }\end{array}$ & $\begin{array}{r}.14 \\
1.45 \\
1.50 \\
3.41 \\
\text { Alkaline. }\end{array}$ & $\begin{array}{r}2.19 \\
\text { None. } \\
\text { None. } \\
\text { Alkaline. }\end{array}$ \\
\hline
\end{tabular}

Soil No. 186, producing fine plants, contains much lime, but only a small amount of carbonate of lime. No. 1S7, a good soil, contains no carbonate of lime. No. 230, also good, contains no carbonate of lime, whereas Nos. 229 and 231, the bad soils, contain much carbonate.

\section{SOIL SURVEY VIII.}

Plantation of Sucesores de Frontera, to the north of Mayaguez playa: About 2 acres were planted with Cabezona pineapples in a coconut grove bordering the shore. The soil was a loose sand, but so low that the drainage was poor. About 30 per cent of the plants grew to maturity and bore fruit. The leares of these plants were green, but narrow and spiky. Many of the other plants died or had light green and yellow leaves; there were only a few ivory-white plants. The drainage being poor and the plants not well cared for, no conclusion could fairly be drawn from this case alone. No. 233 is a sample from this field.

On the south side of Mayaguez Bay there are numerous plantings of Red Spanish and Cabezona pineapples in 2 and 4 acre patches. No examples of chlorotic plants were found there. Considering that most of the ficlds are unfertilized the plants have done fairly well. The soil is sandy, but of a different character and origin from that on the opposite side of the bay; No. 232 is a sample. The soil at the south is apparently an alluvial deposit and very old, containing no calcium carbonate, while the soil on the opposite shore, where the chlorotic plants were found, contains many coral and shell particles and was recently built up by the sea.

[Bull. 11] 
Analyses of pineapple soils.

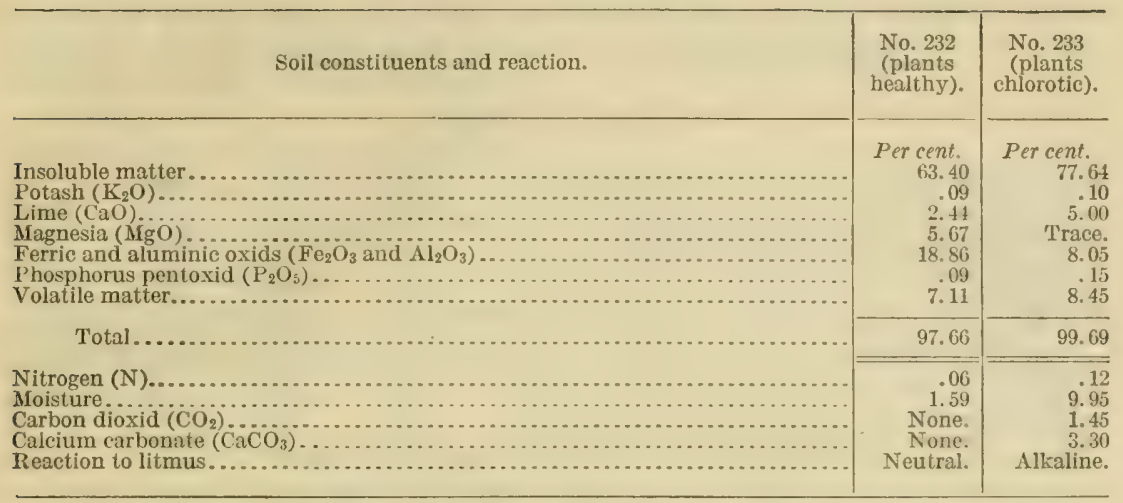

Here again we find the good soil devoid of calcium carbonate, while the bad soil is calcareous and poorly drained.

SOIL SURVEY IX.

Near the road from Rio Piedras to Carolina there are several patches of pineapples showing the characteristic chlorosis. The size of these spots varies from an acre to 200 plants, and they occur on four different plantations. As they are ail similar, they will be considered together. The soil on both sides of the road is for the most part a silicious sand well suited for pineapples, as is evidenced by the large acreage and the uniform success of the plantings.

Directly bordering on the road, however, some patches of yellow and white plants were observed. The soil in these spots when tested with acid effervesced strongly, showing the presence of much carbonate of lime. The soil in the immediate neighborhood, where healthy plants were found, gave no effervescence. A large number of spots in the different fields where healthy plants were growing were tested, and in no case was carbonate of lime present.

The road on which these plantations border is constructed of limestone rock. In the construction and maintenance of this road limestone rock was piled in the fields alongside and there pulverized. During the pulverization much carbonate of lime was incorporated in the soil. It seems that this is the origin of such small areas of calcareous soil as occur in the silicious sand.

Messi's. De Sola and Wolf, at kilometer 9, have about an acre of chlorotic plants. Samples 204 and 205 were taken from the bleached area and samples 207 and 208 from adjacent green areas. The plants in the bleached area are exposed to the effect of more carbonate of lime than appears from the soil analyses, since the drainage water from the road runs down over this spot.

[Bull. 11] 
Analyses of pineapple soils.

\begin{tabular}{|c|c|c|c|c|}
\hline Soll constituents and reaction. & $\begin{array}{c}\text { No. } 204 \\
\text { (plants } \\
\text { ehlorotic). }\end{array}$ & $\begin{array}{l}\text { No. } 205 \\
\text { (plants } \\
\text { chlorotic). }\end{array}$ & $\begin{array}{r}\text { No. } 207 \\
\text { (plants } \\
\text { healthy). }\end{array}$ & $\begin{array}{c}\text { No. } 208 \\
\text { (plants } \\
\text { healthy). }\end{array}$ \\
\hline 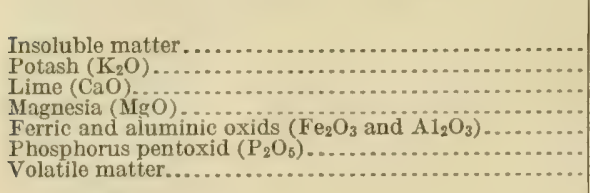 & $\begin{array}{r}\text { Per cent. } \\
86.60 \\
.20 \\
1.05 \\
\text { Trace. } \\
6.23 \\
.04 \\
5.60\end{array}$ & $\begin{array}{r}\text { Per cent. } \\
80.87 \\
.11 \\
.98 \\
\text { Trace. } \\
10.23 \\
.05 \\
7.33\end{array}$ & $\begin{array}{r}\text { Per cent. } \\
88.74 \\
.20 \\
.54 \\
\text { Trace. } \\
6.92 \\
.06 \\
4.71\end{array}$ & $\begin{array}{r}\text { Per cent. } \\
77.14 \\
.12 \\
\text { Trace. } \\
.27 \\
13.84 \\
.05 \\
8.83\end{array}$ \\
\hline Total & 99.72 & 99.57 & 100.17 & 100.25 \\
\hline 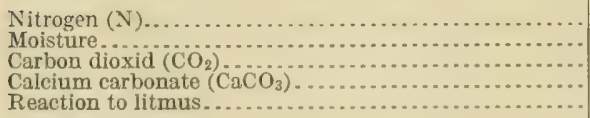 & $\begin{array}{r}.12 \\
1.30 \\
1.58 \\
1.32 \\
\text { Alkaline. }\end{array}$ & $\begin{array}{r}2.14 \\
.38 \\
1.63 \\
\text { Alkaline. }\end{array}$ & $\begin{array}{r}.13 \\
.97 \\
\text { Trace. } \\
\text { Trace. } \\
\text { Acid. }\end{array}$ & $\begin{array}{r}.19 \\
3.15 \\
.00 \\
.00 \\
\text { Acid. }\end{array}$ \\
\hline
\end{tabular}

Mr. Coll y ('uchi, at kilometer 5, has a small patch of about 200 chlorotic plints. No. 299 was taken from such a patch and No. 296 from an area of healthy plants about 5 yards distant. The field there being higher than the road the plants are not exposed to drainage from its surface.

In Mr. Ifubbard's plantation, at kilometer 4, there are about 400 white plants in a hollow below the road. No. 294 is the soil from this patch and No. 297 is a sample taken from a patch of healthy. green plants 10 yards distant.

Mr. Gillies's plantation, at kilometer 3, has about one-tenth acre of strongly chlorotic plants in a hollow below the road. Previous to planting powdered rock from the road had been thrown on this spot. No. 295 is the soil from this bleached spot and No. 298 is from a healthy patch of plants 6 yards distant. While in some of these cases the plants were exposed to water from the road, in no case were the plants suffering from poor drainage.

Analyses of pineapple soils.

\begin{tabular}{|c|c|c|c|c|c|c|}
\hline Soil constituents and reaction. & $\begin{array}{c}\text { No. } 299 \\
\text { (plants } \\
\text { chlorotic). }\end{array}$ & $\begin{array}{r}\text { No. } 296 \\
\text { (plants } \\
\text { healthy). }\end{array}$ & $\begin{array}{c}\text { No. } 294 \\
\text { (plants } \\
\text { chlorotic). }\end{array}$ & $\begin{array}{r}\text { No. } 297 \\
\text { (plants } \\
\text { healthy). }\end{array}$ & $\begin{array}{c}\text { No. } 295 \\
\text { (plants } \\
\text { chlorotic). }\end{array}$ & $\begin{array}{r}\text { No. } 298 \\
\text { (plants } \\
\text { healthy). }\end{array}$ \\
\hline 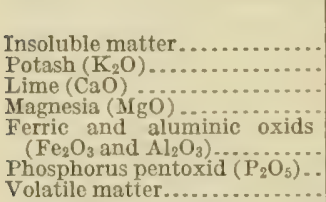 & $\begin{array}{r}\text { Per cent. } \\
76.70 \\
.04 \\
4.18 \\
.05 \\
8.55 \\
.04 \\
9.98\end{array}$ & $\begin{array}{r}\text { Per cent. } \\
84.47 \\
.08 \\
.29 \\
\text { Trace. } \\
.8 .25 \\
.05 \\
7.01\end{array}$ & $\begin{array}{r}\text { Per cent. } \\
75.43 \\
.06 \\
7.55 \\
.14 \\
5.39 \\
.05 \\
11.15\end{array}$ & $\begin{array}{r}\text { Per cent. } \\
91.56 \\
.09 \\
.25 \\
\text { Trace. } \\
4.16 \\
.01 \\
4.03\end{array}$ & $\begin{array}{r}\text { Per cent. } \\
80.04 \\
.08 \\
2.83 \\
.10 \\
8.45 \\
.04 \\
9.16\end{array}$ & $\begin{array}{r}\text { Per cent. } \\
77.62 \\
.05 \\
.37 \\
.13 \\
11.60 \\
.05 \\
9.73\end{array}$ \\
\hline Total & 99.54 & 100.15 & 99.77 & 100.10 & 100.70 & 99.55 \\
\hline $\begin{array}{l}\text { Nitrogen }(\mathrm{N}) \ldots \ldots \\
\text { Moisture } \\
\text { Carbon dioxid }\left(\mathrm{CO}_{2}\right) \\
\text { Calcium carbonate }(\mathrm{CaCO} . \\
\left.\text { Reaction to litmus } \mathrm{CO}_{3}\right)\end{array}$ & $\begin{array}{r}.15 \\
3.35 \\
2.73 \\
6.21 \\
\text { Alkaline. }\end{array}$ & $\begin{array}{r}5.16 \\
.00 \\
.00 \\
\text { Neutral. }\end{array}$ & $\begin{array}{r}3.15 \\
4.70 \\
\text { 10.70 } \\
\text { Alkaline. }\end{array}$ & $\begin{array}{r}2.11 \\
.48 \\
.00 \\
.00 \\
\text { Alkaline. }\end{array}$ & $\begin{array}{r}4.14 \\
1.61 \\
3.66 \\
\text { Alkaline. }\end{array}$ & $\begin{array}{r}9.20 \\
9.02 \\
.00 \\
.00 \\
\text { Neutral. }\end{array}$ \\
\hline
\end{tabular}

[Bull. 11] 
It can be seen that all the above soils on which chlorotic plants were growing are calcareous or rendered so by the drainage water, while none of the good soils contain carbonate of lime.

SOIL SURVEY $\mathrm{X}$.

Samples were also taken from fields where pineapples were growing well on soils which had the same physical character as those producing the chlorotic plants. No chlorotic plants were observed in these fields or in the immediate vicinity. Nos. 175 and 176 are samples from Campo Alegre, 177 from Manati, 179 and 180 from Rio Piedras.

Analyses of pineapple soils (plants healthy).

\begin{tabular}{|c|c|c|c|c|c|}
\hline Soil constituents and reactions. & No. 175. & No. 177 . & No. 179. & No. 180. & No. 176. \\
\hline 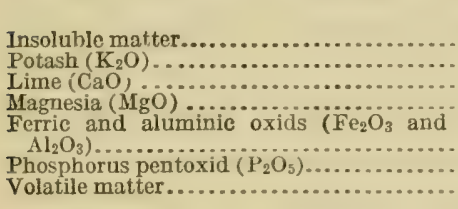 & $\begin{array}{r}\text { Per cent. } \\
89.78 \\
.04 \\
.14 \\
\text { Trace. } \\
5.93 \\
.04 \\
3.93\end{array}$ & $\begin{array}{r}\text { Per cent. } \\
95.04 \\
.09 \\
.17 \\
\text { Trace. } \\
1.76 \\
.03 \\
2.86\end{array}$ & $\begin{array}{r}\text { Per cent. } \\
89.99 \\
.06 \\
\text { Trace. } \\
\text { Trace. } \\
5.08 \\
.04 \\
4.50\end{array}$ & $\begin{array}{r}\text { Per cent. } \\
96.25 \\
.04 \\
\text { Trace. } \\
\text { Trace. } \\
.70 \\
.04 \\
2.92\end{array}$ & $\begin{array}{r}\text { Percent. } \\
97.12 \\
.03 \\
.15 \\
\text { Trace. } \\
1.88 \\
.03 \\
1.30\end{array}$ \\
\hline Total. & 99.86 & 99.95 & 99.67 & 99.95 & 100.51 \\
\hline 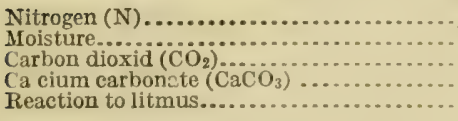 & $\begin{array}{r}.09 \\
3.34 \\
: 00 \\
.00 \\
\text { Acid. }\end{array}$ & $\begin{array}{r}.05 \\
3.15 \\
.00 \\
.00 \\
\text { Acid. }\end{array}$ & $\begin{array}{r}.11 \\
1.51 \\
.00 \\
.00 \\
\text { Acid. }\end{array}$ & $\begin{array}{r}.09 \\
.59 \\
.00 \\
.00 \\
\text { Acid. }\end{array}$ & $\begin{array}{r}.09 \\
.50 \\
.00 \\
.00 \\
\text { Acid. }\end{array}$ \\
\hline
\end{tabular}

It will be seen that these good soils are also without calcium carbonate.

The results of the soil surveys are as follows:

Of the 43 samples of soil analyzed, 22 were taken from areas where the pineapples were chlorotic and 21 from areas where they were healthy.

The good soils contain, on an average, 0.11 per cent potash $\left(\mathrm{K}_{2} \mathrm{O}\right)$, 0.07 per cent phosphoric acid $\left(\mathrm{P}_{2} \mathrm{O}_{5}\right)$, and 0.14 per cent nitrogen $(\mathrm{N})$. The bad soils average 0.12 per cent potash $\left(\mathrm{K}_{2} \mathrm{O}\right), 0.10$ per cent phosphoric acid $\left(\mathrm{P}_{2} \mathrm{O}_{5}\right)$, and 0.17 per cent nitrogen $(\mathrm{N})$. Thus the soils producing chlorotic plants average higher in nutrients than the soils producing healthy plants.

The chief difference between the soils producing chlorotic and healthy plants lies in the content of calcium carbonate $\left(\mathrm{CaCO}_{3}\right)$. The bad soils contain from 1.86 to 79.76 per cent of calcium carbonate $\left(\mathrm{CaCO}_{3}\right)^{1}$ All the good soils contain less than 1.15 per cent $\mathrm{CaCO}_{3}$ and most of them no lime in the form of carbonate.

1 Nos. 204 and 205 are excepted as here the plants were exposed to the action of a greater amount, of lime than appears in the soil analyses.

$412^{\circ}-$ Bull. 11- $11-3$ 
From an average of the results and from the rather striking nature of the evidence in particular cases there seems no doubt but that the chlorosis of the pineapple plants is due to the high content of calcium carbonate in the soil.

\section{PINEAPPLE SOILS OF OTHER COUNTRIES.}

No analyses of Cuban pineapple soils are available, but from a statement by Prof. F. S. Earle, at one time director of the experiment station at Santiago de las Vegas, it appears that pineapple plantings on the calcareous soils of Cuba have been unsuccessful. ${ }^{1}$

J. C. Brunnich, chemist of the experiment station of Queensland, in a personal communication, reports a disease of the pineapple there, induced by poor drainage, but says: "We have no experience of pines grown on a strongly calcareous soil."

The Hawaiian pineapple soils reported by W. P. Kelley ${ }^{2}$ average about 0.50 per cent of $\mathrm{CaO}$, most of them being acid in reaction, and, so far as reported, none of them being calcareous. Certain soils in Hawaii were found unfarorable for pineapples due to the high content of soluble manganese. This is interesting in illustrating the sensitiveness of the pineapple to the chemical character of the soil.

From numerous analyses by Miller and IIume it appears that the good pineapple soils of Florida mainland contain no carbonate of lime. $^{3}$ The type of soil which produces the best pineapples there contains less than 0.20 per cent of $\mathrm{CaO}$ and about 99 per cent of insoluble matter. Webber reports that "many plantations have been put out on shell land but have uniformly failed." A As sea shells are composed of calcium carbonate, such soils would be calcareous.

In the cultivation of pineapples in the Florida Keys, however, we have an apparent exception to the proposition that pineapples will not grow well on a calcareous soil. Rolfs describes conditions there as follows:

These are islands near the coast of southern Florida. *** They have a coralline foundation, making a rather porous substratum. *** In many cases soil, in the ordinary sense, can not be said to exist. In some instances the pineapple planter is obliged to choose the spot that has enough decayed vegetable matter to hold the plant in place on the coralline rock. The greater part, or nearly all, of the plant food is located in the small quantity of decaying vegetable matter; consequently it is soon exhausted. ${ }^{5}$

1 Prof. Earle, in a personal communication, states: "The commercial pineapple fields of Cuba are practically all on the 'red lands.' These soils always overlie coral rock and are probably derived from it, but they carry very little lime, the carbonate of lime seeming to have practically all leached out. These soils though stiff and heavy are very permeable and the water passes down through them readily. Pineapples also thrive on certain sandy lands, but they do not do well on heary black lands. These usually carry a considerable percentage of lime, and they are often underlain by 'coco,' a soft material that is largely carbonate of lime. Fields planted on these lands produce inferior fruit and usually soon die."

Hawaii Sta. Rpt. 1909, p. 58.

Florida Sta. Bul. 68.

1 U. S. Dept. Agr. Yearbook 1895, p. 273.

5U. \$. Dept. Agr., Farmers' Bul. 140, p. 14.

[Bull. 11] 


\section{Niller and Hume ${ }^{1}$ report:}

It is the custom to use no fertilizers on the Keys where this kind of soil is found and the land becomes exhausted after yielding three or four crops of pineapples. At the end of this time the soil is completely worn out, and little more than the bare rock remaining it is abandoned.

The analysis of such a soil shows nearly 5 per cent of lime, 0.30 per cent of potash, 0.95 per cent of phosphorus pentoxid, 24.55 per cent of humus, and 2.65 per cent of nitrogen. Although this contains a high percentage of calcium it is probable, by comparing it with the following analyses, that none of this lime was present as carbonate.

To investigate this matter further, samples of soil were secured from two of the Keys through the kindness of the planters. The samples received are hardly soils in the strict sense of the word; they are composed exclusively of leaf mold, undecomposed leaves, and coral particles. Samples Nos. 209 and 210 were received from Mr. T. J. Johnson, of Planter, Fla., and Nos. 214 and 219 from Mrr. Edward Gottfried, of Key Largo, Fla. No. 219 is a virgin soil and No. 214 is from a pineapple field which is now abandoned.

Analyses of pineapple soils from Florida Keys (plants healthy).

\begin{tabular}{|c|c|c|c|c|}
\hline Soil constituents and reaction. & No. 209. & No. 210. & No. 214. & No. 219 . \\
\hline $\begin{array}{l}\text { Insoluble matter } \\
\text { Potash }\left(\mathrm{K}_{2} \mathrm{O}\right) \\
\text { Lime }(\mathrm{CaO}) \\
\mathrm{M} \text { agnesia }(\mathrm{MgO}) \\
\text { Ferric and aluminic oxids }\left(\mathrm{Fe}_{2} \mathrm{O}_{3} \mathrm{~A}_{2} \mathrm{O}_{3}\right) \\
\text { Phosphorus pentoxid }\left(\mathrm{P}_{2} \mathrm{O}_{5}\right) \\
\text { Volatile matter } \ldots \ldots\end{array}$ & $\begin{array}{r}\text { Per cent. } \\
3.10 \\
.23 \\
21.13 \\
.56 \\
1.97 \\
.40 \\
71.83\end{array}$ & $\begin{array}{r}\text { Per cent. } \\
6.62 \\
.29 \\
20.34 \\
.69 \\
5.29 \\
: 30 \\
66.92\end{array}$ & $\begin{array}{r}\text { Per cent. } \\
3.15 \\
17.19 \\
.17 \\
2.44 \\
.25 \\
76.99\end{array}$ & $\begin{array}{r}\text { Percent. } \\
2.54 \\
.18 \\
10.96 \\
\text { Trace. } \\
3.11 \\
.22 \\
83.20\end{array}$ \\
\hline Total. & 99.22 & 100.45 & 100.00 & 100.21 \\
\hline $\begin{array}{l}\text { Nitrogen (N) } \\
\text { Moisture } \\
\text { Carbon dioxid }\left(\mathrm{CO}_{2}\right) \\
\text { Calcium carbonate }\left(\mathrm{CaCO}{ }_{3}\right) \\
\text { Reaction to litmus . . . . }\end{array}$ & $\begin{array}{r}1.89 \\
19.84 \\
1105 \\
25.14 \\
\text { Alkaline. }\end{array}$ & $\begin{array}{r}1.97 \\
20.05 \\
9.18 \\
20.88 \\
\text { Alkaline. }\end{array}$ & $\begin{array}{r}2.41 \\
13.60 \\
7.59 \\
17.27 \\
\text { Alkaline. }\end{array}$ & $\begin{array}{r}2.61 \\
19.59 \\
1.90 \\
4.32 \\
\text { Alkaline. }\end{array}$ \\
\hline
\end{tabular}

It will be seen that these "soils" are remarkable for their great content of organic matter (as is shown by the high percentages of volatile matter and nitrogen) and for their richness in plant food, which must be present in a form that is quickly available to the plants. The content of lime is high, and while a large part is combined with the humus there is still a high percentage of calcium carbonate. It is then evident that pineapples will stand a large amount of calcium carbonate in the medium in which they grow providing a very large amount of organic matter and humus is also present.

The soil surveys of Porto Rico and the information obtainable from Cuba, Hawaii, Queensland, and the Florida mainland, concur in showing many cases of the failure of pineapples on calcareous soils

[Bull. 11]

1 Loc. cit. 
and no instances of healthy plantings on this soil type. The experience of planters on the Florida Keys shows clearly that pineapples will grow in a calcareous soil providing it contains a very large amount of humus. This exception will be considered further on.

\section{POT EXPERIMENTS WITH DIFFERENT TYPES OF SOIL.}

The soil surveys having shown the calcareous nature of the Porto Rico soils unsuited for pineapples, it was desirable to see whether soils growing healthy plants would be rendered incapable of producing normal plants by the addition of calcium carbonate. For this purpose a series of pot experiments were carried out.

Previous to this, however, certain preliminary experiments were made to show whether or not the trouble was to be attributed to the character of the soil, and also to explain certain apparent exceptions that occurred in the field. These experiments are here given in brief.

On Mr. Noble's plantation (see p. 8) some isolated patches of green plants were observed in the midst of chlorotic areas. It was desirable to see whether these patches of plants remained green due to differences in the soil or to individual variations in the plants themselves. Soil from such a patch of green plants together with the plants themselves were shipped to the station, also the soil and plants from a chlorotic area. The soil from the green plants is No. 102, that from the chlorotic plants is No. 101 (see p. 10). These soils were placed in pots holding $S$ pounds of moisture-free soil and were fertilized abundantly from time to time. Five chlorotic plants were placed in soil No. 101 and 5 in No. 102. Five of the green plants were placed in soil No. 101 and 5 in No. 102. Ten chlorotic plants were placed in a good garden soil free from calcium carbonate. The green plants in both soils 101 and 102 remained green for some time, but as their growth increased they later became chlorotic. The chlorosis appeared as rapidly in soil 101 as in soil 102. All the chlorotic plants placed in soils 101 and 102 remained chlorotic and grew but little. The chlorotic plants placed in the garden soil soon recovered their green color and made a good growth. IIalf of these recovered plants were then again returned to soils 101 and 102 and here they again became chlorotic and growth ceased.

It is apparent from this that soils 101 and 102 are practically the same, and that the occurrence of green plants on one of them was due to the fact that the slips planted there were of greater vigor than the others. Field results confirmed this view, as later the isolated green plants on this plantation lost their color. The fact that chlorotic plants recovered in the good garden soil and again became chlorotic on returning to the original soil shows that the chlorosis was probably induced by the soil and is not an organic disease.

The following experiments and the success of the transplanted plants on Mr. Noble's plantation (see p. 8) confirm this.

[Bull. 11] 
Soil and chlorotic plants were secured from Luquillo (see p. 9). The soil was placed in pots and well fertflized. Five chlorotic plants were placed in the original soil; these remained chlorotic with very little growth. Five chlorotic plants placed in a river sand devoid of calcium carbonate became green and made a good growth. Five healthy slips placed in the Luquillo soil grew well for a time and then became chlorotic.

Chlorotic plants were also secured from the plantation of Messrs. De Sola and Wolff (see p. 15). These on being placed in pots of the river sand became green and grew normally.

These three preliminary experiments showed plainly that the chlorosis is induced by an unsuitable soil condition, probably the presence of too much carbonate of lime.

Sandy soil was then secured from a plantation near Mayaguez where pineapples were growing well. The soil is No. 232 (see p. 15). Carbonate of lime in the form of ground sea shells was added to this soil in such amounts that different pots contained 5, 10, 13, and 17 per cent of calcium carbonate. Five equal Red Spanish slips were planted. The check plant in the soil containing no calcium carbonate remained green throughout the experiment, while all the other plants became chlorotic, the chlorosis appearing first and being most intense in those pots containing the greatest amount of lime.

Experiments were then made on a larger scale to see if the addition of calcium carbonate to a soil would cause it to produce chlorotic plants. The details of the experiments follow.

The plants were grown in pots that contained 40 pounds of moisturefree soil. These were exposed in the open on tables that were protected from ants and mealy bugs. Water was supplied only a few times in the course of the experiment, as the rainfall was sufficient to maintain a good supply of moisture during the period. The size of the pots and the frequent rains prevented any appreciable variations occurring in the water content of individual pots due to differences in the transpiration of the plants. In each pot only one plant was grown, so that practically as much soil was at the disposal of the plant as under field conditions. The experiments were run in series of five, that is, in every case there were five pots receiving the same treatment.

The pots were planted with suckers obtained from healthy plants grown on the station. Previous to planting, all slips were fumigated with hydrocyanic-acid gas to kill any mealy bugs or other pests. Five different sizes of slips, varying from 6 to 14 inches in length, were used in each lot of five pots, but the slips in each lot of five were equal to those of every other lot of five. Slips of different sizes were used for the purpose of seeing whether the appearance of the chlorosis was affected by the initial vigor of the slip.

[Bull. 11] 
Experiments were made with three different types of soil-with a loose river sand, with a loamy clay, and with a soil composed chiefly of organic matter. This latter soil was prepared artificially by mixing a small amount of sandy soil with well-weathered manure.

The analyses of the soils are as follows:

Analyses of soils used in pot experiments.

Soll constituents and reaction.

\begin{tabular}{|c|c|c|}
\hline $\begin{array}{c}\text { No. } 213 \\
\text { (sandy soil). }\end{array}$ & $\begin{array}{l}\text { No. } 18 \\
\text { (clay loam } \\
\text { soil). }\end{array}$ & $\begin{array}{c}\text { No. } 222 \\
\text { (soil rich } \\
\text { in humus). }\end{array}$ \\
\hline $\begin{array}{r}\text { Percent. } \\
67.38 \\
.01 \\
1.23 \\
2.21 \\
21.90 \\
.08 \\
6.59\end{array}$ & $\begin{array}{r}\text { Percent. } \\
60.38 \\
.30 \\
.85 \\
3.58 \\
23.91 \\
.20 \\
11.55\end{array}$ & $\begin{array}{r}\text { Percent. } \\
47.49 \\
.49 \\
3.82 \\
2.92 \\
11.49 \\
.55 \\
33.25\end{array}$ \\
\hline 99.40 & 100.77 & 100.00 \\
\hline $\begin{array}{r}7.05 \\
\text { None. } \\
\text { None. } \\
\text { Neutral. }\end{array}$ & $\begin{array}{r}11.46 \\
\text { None. } \\
\text { None. } \\
\text { Neutral. }\end{array}$ & $\begin{array}{r}.69 \\
5.83 \\
\text { None. } \\
\text { None. } \\
\text { Acid. }\end{array}$ \\
\hline
\end{tabular}

Lime was added to these soils in the form of carbonate. The limestone used was of coralline origin and occurs naturally in a finely disintegrated state. The use of this material made it possible to imitate closely natural conditions, as this limestone forms the subsoil of many fields and is of the same origin as much of the calcium carbonate occurring in Porto Rico calcareous soils. ${ }^{1}$ In all experiments except No. IV such a limestone, obtained from Tallaboa, was used. The analysis is given below under No. 216. In experiment IV a limestone of the same kind but containing more magnesium was used, the analysis of which is given under 211 .

Analyses of limestone used in pot experiments.

\begin{tabular}{|c|c|c|c|}
\hline & Soll constituents. & $\begin{array}{l}\text { No. } 216 \\
\text { (used in } \\
\text { experi- } \\
\text { ments I, } \\
\text { II, III). }\end{array}$ & $\begin{array}{l}\text { No. } 211 \\
\text { (used in } \\
\text { experiment } \\
\text { IV). }\end{array}$ \\
\hline $\begin{array}{l}\text { Siliea and sand }\left(\mathrm{SiO}_{2}\right) \\
\text { Iron and alumina }\left(\mathrm{Fe}_{2} \mathrm{O}_{3} \text { and }\right. \\
\text { Lime }(\mathrm{CaO}) \\
\text { Mragnesium }(\mathrm{MgO}) \\
\text { Loss on ignition. }\end{array}$ & 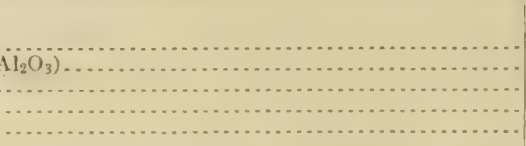 & $\begin{array}{r}\text { Percent. } \\
8.41 \\
1.90 \\
50.76 \\
.84 \\
38.81\end{array}$ & $\begin{array}{r}\text { Percent. } \\
0.20 \\
.68 \\
49.82 \\
4.86 \\
44.32\end{array}$ \\
\hline Tot? & & 100.72 & 99.88 \\
\hline
\end{tabular}

The pots were all tertilized alike from time to time. The fertilization was rather more liberal than necessary in order to show beyond doubt that the chlorosis was not induced by lack of nitrogen, phosphorus, or potash. Tankage, sodium nitrate, sulphate of potash,

1 The effectiveness in the soil of calcium and magnesium carbonate from different sources is compared by D. Meyer (Landw. Jahrb., $33(1904)$, p. 371).

[Bull, 11] 


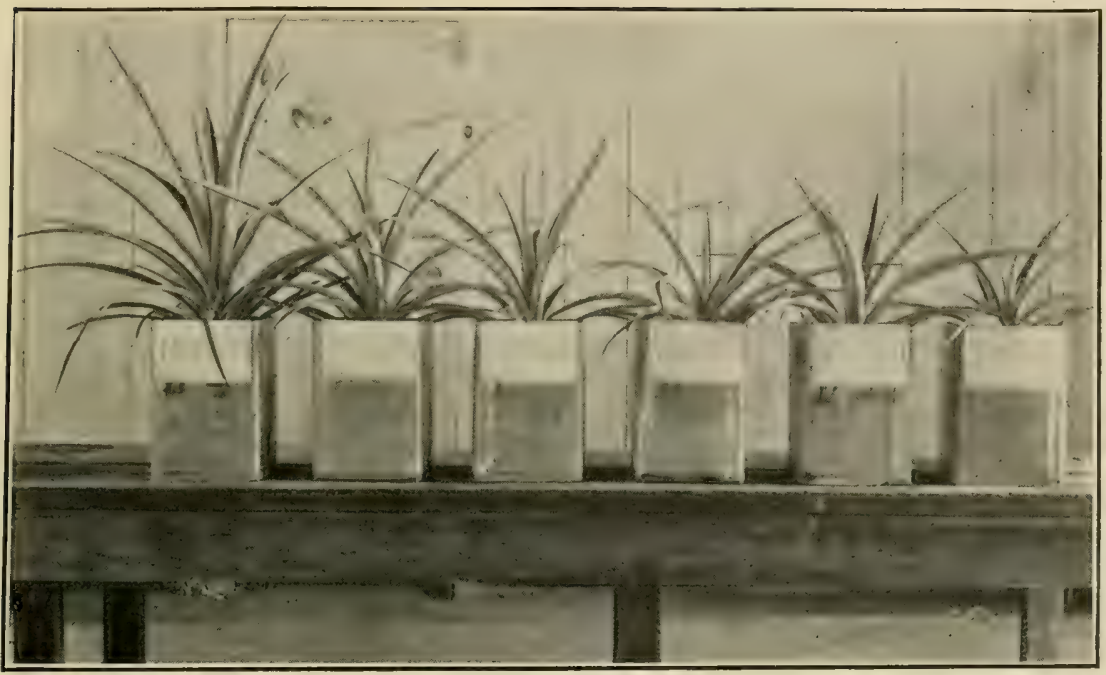

Fig. 1.-EFFEct of Carbonate of LIME ON THE GROWTH OF PINEAPPLES.

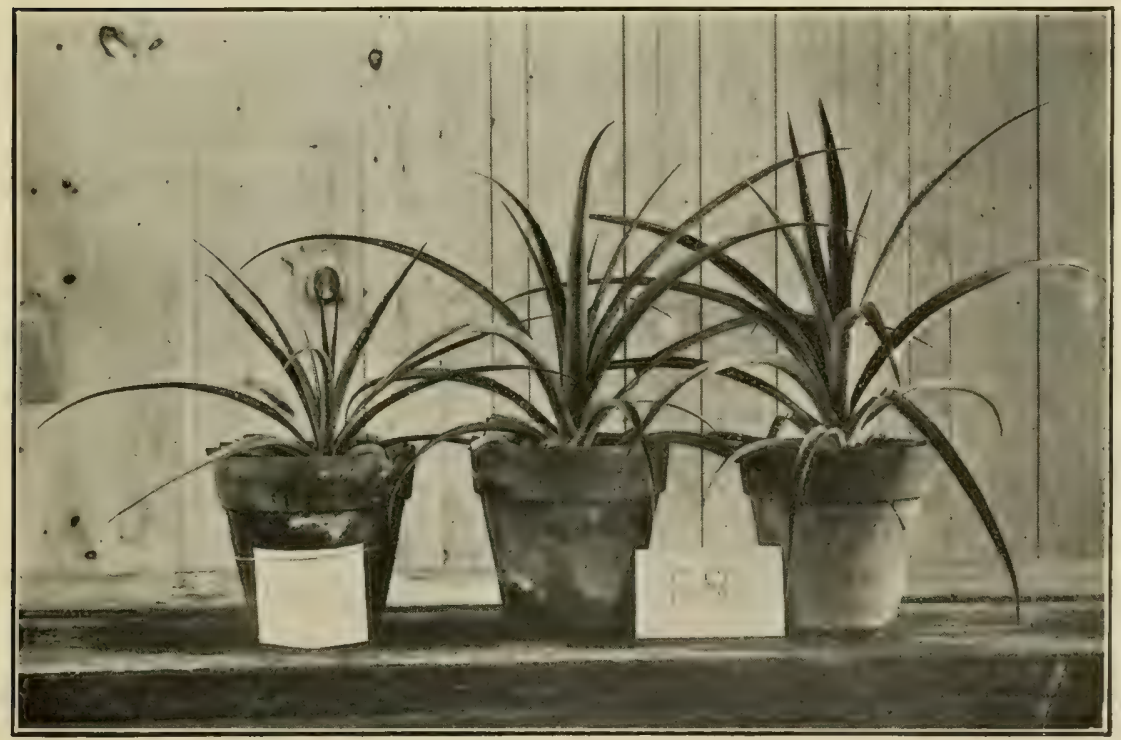

Fig. 2.-Effect of Ferrous Sulphate on Chlorotic Pineapple Plants. 

and acid phosphate were mixed with the soil in such quantities that during the period of growth each pot receiverl 4.1 grams of nitrogen, 3.1 grams of phosphoric acid, and 6.7 grams of potash. The fertilizer was given in different applications to prevent too great a quantity of soluble salts being present at one time and also because there was probably a certain loss by leaching caused by the heavy showers.

The plants were grown for a period of 10 months, and during this time the check plants made a growth equal or superior to that of plants in the field. A record was kept of each plant in regard to the appearance of chlorosis. After 10 months' growth the plants were cut and weighed in the green condition.

The principal purpose of the experiments was qualitative-to observe the effect of calcium carbonate in producing a chlorotic appearance of the plants, but the comparative weights show in a general way the condition of the plants and give an idea of its effect on the growth. Accurate quantitative data of small differences in growth can not be obtained in pot experiments with pineapples, as it is impracticable to grow enough individuals to secure a fair average.

In experiment I the sandy soil No. 213 was used and the limestone No. 216. The five check pots contained no lime; the other lots of five pots each contained, respectively, 10, 20,30,40, and 50 per cent of calcium carbonate. Suckers of Red Spanish pineapples were planted. In the next table are given the appearance of the plants at four, six, and nine months, and the average green weight.

The object of the experiment was to see whether the addition of calcium carbonate to a good sandy soil would cause it to produce chlorotic plants. By consulting the table it will be seen that all the check plants made a good growth and remained dark green during the 10 months; that all the plants in pots containing carbonate of lime showed varying degrees of chlorosis and a great depression in growth; that the chlorosis was most intense in the pots containing the greatest amount of lime. (PI. II, fig. 1.)

Results of experiment in which calcium carbonate was added to sandy soil.

\begin{tabular}{|c|c|c|}
\hline $\begin{array}{l}\mathrm{Amount} \text { of } \\
\mathrm{CaCO}_{3} \text { in soil. }\end{array}$ & Appearance of plants during growth. & $\begin{array}{l}\text { A verage } \\
\text { green } \\
\text { weight of } 5 \\
\text { plants at } \\
\text { end of } 10 \\
\text { months. }\end{array}$ \\
\hline $\begin{array}{l}\text { Check......... } \\
10 \text { per cent... }\end{array}$ & $\begin{array}{l}\text { All plants dark green throughout the experiment....... } \\
\text { Color of all } 5 \text { plants lighter than cheek at fourth month; at sixth month } 2\end{array}$ & $\begin{array}{r}\text { Grams. } \\
1,022 \\
596\end{array}$ \\
\hline 20 per cent. & $\begin{array}{l}\text { plants slightly chlorotic; at ninth month all slightly chlorotic. } \\
\text { At fourth month } 2 \text { plants slightly chlorotic, others light green; at sixth } \\
\text { month all slightly chlorotic; at ninth month all } 5 \text { chlorotic. }\end{array}$ & 584 \\
\hline 30 per cent. & $\begin{array}{l}\text { At fourth month all } 5 \text { plants light green; at sixth month } 4 \text { plants chlorotic; } \\
\text { at ninth month all chlorotic and } 3 \text { very strongly. }\end{array}$ & $623^{\circ}$ \\
\hline 40 per cent. & $\begin{array}{l}\text { At fourth month } 4 \text { plants slightly chlorotic and } 1 \text { plant light green; at sixth } \\
\text { month all chlorotic; at ninth month all } 5 \text { strongly chlorotic. }\end{array}$ & 549 \\
\hline 50 per cent. & $\begin{array}{l}\text { At fourth month all slightly chlorotic; at sixth month all chlorotic; at ninth } \\
\text { month all } 5 \text { strongly chlorotic. }\end{array}$ & 400 \\
\hline
\end{tabular}

[Bull. 11] 
Experiment II is the same as experiment I throughout, except that the loamy clay soil No. 18 was used instead of the sandy soil. The results are given in the table below.

The object of this experiment was to see whether the chlorosis would be as intense in a calcareous clay as in a sandy soil. The results show that check plants had a good color throughout the experiment and made a fair growth, though not equal to that of the check plants in experiment I; that 10 per cent of calcium carbonate did not produce as intense a chlorosis as the same amount of lime in a sandy soil; that 20 to 50 per cent of calcium carbonate caused as intense a chlorosis in the clay soil as in the sand, though the plants made a greater growth.

Results of experiment in which calcium carbonate was added to loamy soil.

\begin{tabular}{|c|c|c|}
\hline $\begin{array}{l}\mathrm{Amount} \\
\mathrm{CaCO}_{3} \text { in soil. }\end{array}$ & Appearance of plants during growth. & $\begin{array}{l}\text { Average } \\
\text { green } \\
\text { weight of } 5 \\
\text { plants at } \\
\text { end of } 10 \\
\text { months. }\end{array}$ \\
\hline Check. & All plants dark green throughout the experiment.... & Grams. \\
\hline 10 per cent. & $\begin{array}{l}\text { Color of } 2 \text { plants lighter than cheek at fourth month; at sisth month } 2 \text { plants } \\
\text { slightly chlorotic; at ninth month } 1 \text { plant chlorotic, } 4 \text { plants inferior to } \\
\text { check in color. }\end{array}$ & 622 \\
\hline 20 per cent. & $\begin{array}{l}\text { Three plants showed symptons of chlorosis at fourth month; at sixth month } \\
3 \text { plants chlorotic, } 1 \text { slightly affected; at ninth month } 3 \text { plants chlorotic, } \\
2 \text { slightly affected. }\end{array}$ & 685 \\
\hline 30 per cent. & $\begin{array}{l}\text { Color of } 5 \text { plants lighter than check at fourth month; at sixth month } 3 \text { chlorotic } \\
\text { at center, } 1 \text { slightly chlorotic; at ninth month all } 5 \text { plants chlorotic. }\end{array}$ & 650 \\
\hline 40 per cent. & $\begin{array}{l}\text { At fourth month } 1 \text { plant strongly chlorotic, } 2 \text { plants color equal to check, } 2 \\
\text { plants color lighter than eheck; at sixth month all } 5 \text { plants chlorotic; at } \\
\text { ninth month all plants strongly eblorotic. }\end{array}$ & 471 \\
\hline 50 per cent & $\begin{array}{l}\text { At fourth month } 1 \text { plant slightly chlorotic, } 4 \text { plants color lighter than check; } \\
\text { at sixth month all } 5 \text { plants chlorotic; at ninth month all plants strongly } \\
\text { chlorotic. }\end{array}$ & 534 \\
\hline
\end{tabular}

Experiment III is the same as experiment I throughout, except that the soil rich in humus (No. 222) was used. The results are given in the table following.

The object of this experiment was to see whether the addition of calcium carbonate to a soil exceptionally rich in organic matter would cause it to produce chlorotic plants. Briefly the results were: The check plants maintained a good color and made an exceptional growth; the plants in the pots with 10 to 30 per cent of calcium carbonate were practically equal to the checks in color and growth; three plants in the pots with 40 per cent calcium carbonate showed chlorosis at the sixth month but recovered later, the growth being about equal to the checks; the five plants in the pots with 50 per cent calcium carbonate were slightly chlorotic at six months but all except one recovered their green color later. The results of this experiment are in harmony with the conditions obtaining in the Florida-Keys. They show that the tendency of calcium carbonate to cause chlorosis is counteracted by

[Bull. 11] 
a large amount of organic matter, but that when the proportion of organic matter to calcium carbonate falls below a certain point chlorosis is produced in spite of the large amount of humus.

Results of experiment in which calcium carbonate was added to a soil rich in humus.

\begin{tabular}{|c|c|c|}
\hline $\begin{array}{l}\text { Amount of } \\
\mathrm{CaCO}_{3} \text { in soil. }\end{array}$ & Appearance of plants during growth. & $\begin{array}{l}\text { Average } \\
\text { green } \\
\text { weight of } 5 \\
\text { plants at } \\
\text { end of } 10 \\
\text { months. }\end{array}$ \\
\hline & & Grams. \\
\hline Cheek.......... & All plants dark green throughout the experiment............. & 1,137 \\
\hline 10 per cent.... & All plants equal to check in color throughout the experiment............ & 812 \\
\hline 20 per cent..... & 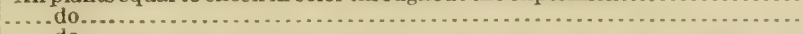 & 1,048 \\
\hline 30 per cent..... & - do do... . . & 1,117 \\
\hline 40 per cent..... & $\begin{array}{l}\text { At fourth month color of all plants equal to check; at sixth month } 2 \text { plants } \\
\text { chlorotic and } 1 \text { slightly chlorotic; at ninth montis } 1 \text { plant slightly chlorotic, } \\
\text { others equal to check. }\end{array}$ & 1,006 \\
\hline 50 per cent..... & $\begin{array}{l}\text { At fourth month color of all plants equal to check at sixth month all plants } \\
\text { strongly chlorotic; at ninth month } 1 \text { plant chlorotic, } 4 \text { very slightly chlo- } \\
\text { rotic. }\end{array}$ & 1,070 \\
\hline
\end{tabular}

Experiment IV is the same as experiment I throughout, except that the magnesia limestone (No. 211) was used, instead of No. 216. As but 75 pounds of this limestone was available, only the effect of soils containing 10 and 30 per cent of the combined carbonates (of lime and magnesia) was tried. The results are given in the table below.

The object of this experiment was to see if increasing the available magnesium in the soil would lessen the chlorosis. The results were: The check plants maintained a good green growth; the plants in all the pots with the magnesium limestone became chlorotic; the chlorosis was fully as intense as in the parallel experiment with the limestone low in magnesia (experiment $\mathrm{I}$ ). It is apparent that increasing the ratio of magnesium carbonate to calcium carbonate from $1: 51$ to 1: 9 has no beneficial effect in diminishing the chlorosis or increasing the growth of the plants.

Results of experiment in which limestone containing 10 per cent of magnesium carbonate was added to sandy soil.

\begin{tabular}{|c|c|c|}
\hline $\begin{array}{c}\text { Amount of } \\
\text { combined car- } \\
\text { bonates (lime } \\
\text { and magnesia) } \\
\text { in soil. }\end{array}$ & Appearance of plants during growth. & $\begin{array}{l}\text { Average } \\
\text { green } \\
\text { weight of } 5 \\
\text { plants at } \\
\text { end of } 10 \\
\text { months. }\end{array}$ \\
\hline Check. & All plants dark green throughout the experiment .......... & Grams. \\
\hline 10 per cent & $\begin{array}{l}\text { At fourth month color of all plants poorer than the check; at sixth month } \\
\text { plant dead, } 2 \text { plants slightly chlorotic; at ninth month all plants slightly } \\
\text { chlorotic. }\end{array}$ & 508 \\
\hline 30 per cent ..... & $\begin{array}{l}\text { At fourth month } 1 \text { plant chlorotic, } 4 \text { plants color inferior to check; at sixth } \\
\text { month } 1 \text { plant strongly chlorotic, } 4 \text { plants very slightly chlorotic; at ninth } \\
\text { month all intensely chlorotic. }\end{array}$ & 358 \\
\hline
\end{tabular}

[Bull. 11] 
In addition to the pot cultures an experiment was made under natural conditions in the following manner: Four holes, 20 by 10 feet and 2 feet deep, were dug and filled with prepared soil. The plats were surrounded by a ditch and separated from each other by 3 feet of clay soil. One plat was made up of a loamy soil containing no carbonate of lime. The other three plats contained respectively 10 per cent, 25 per cent, and 50 per cent of calcium carbonate. The limestone used was No. 216 and was very thoroughly mixed with the soil. In each plat 16 Red Spanish slips were planted. The plants were here growing under perfectly natural conditions of moisture, temperature, and root space.

All the plants in the check plat, with no carbonate of lime, made a good green growth throughout the experiment. The plants in the plat with 10 per cent of calcium carbonate at the end of five months were distinctly inferior in color, being a very light green. At the end of seven months 11 plants, which had made a fair growth, were strongly chlorotic; the remaining 5 plants, which had grown but little, were only slightly chlorotic. At the tenth month they were all slightly chlorotic. The plants in the third plat, with 25 per cent of calcium carbonate, were slightly chlorotic at the fifth month. At the seventh month the 12 plants which had made a fair growth were very strongly chlorotic, being creamy white in color, while the remaining 4 plants, which had made little growth, were slightly chlorotic. At the tenth month all plants were strongly chlorotic. The plants in the fourth plat, with 50 per cent of calcium carbonate, were slightly chlorotic at the fifth month, and at the seventh month the 7 largest plants were creamy white, the remaining 9 plants of little growth were plainly though not intensely chlorotic. At the tenth month all were intensely chlorotic. At the end of 10 months the plants were cut and the average green weight of the plants was. as follows:

\section{Average weight of plants.}

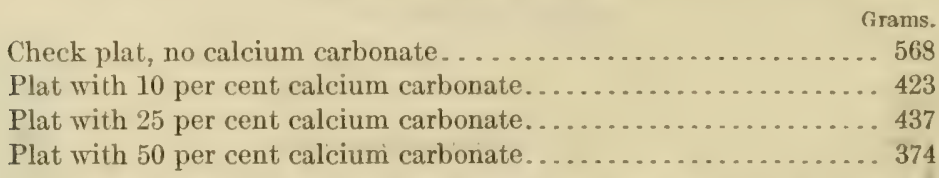

The results of the experiments with plants grown in pots and in small field plats were as follows:

Plants grown on sandy and loamy soils to which natural carbonate of lime was added became chlorotic. Plants grown in a soil which was practically pure organic matter showed no chlorosis until the percentage of carbonate of lime reached 50 per cent.

[Bull. 11] 
Limestone containing 10 per cent of magnesium carbonate produced as intense a chlorosis as a limestone containing 1 per cent of magnesium carbonate.

The plants usually showed a slight chlorosis four or five months after planting and at the ninth month were strongly chlorotic. In all the experiments it was observed that the chlorosis was somewhat dependent on the growth. Plants which grew slowly at first did not become chlorotic as quickly as those which made a quick start. Also, the plants originating from small slips became chlorotic much sooner than those originating from large ones. Plants coming from very small but vigorous slips, which made a quick growth at the start, were the type that showed the chlorosis first and most intensely.

From these observations it would appear that the chlorosis was dependent either on the exhaustion of a nutrient stored in the slip, which the plant was later unable to obtain from the calcareous soil, or on the absorption of an injurious amount of an element from the soil.

\section{CONCLUSIONS FROM SOIL INVESTIGATIONS.}

The results of the culture experiments confirm the conclusions arrived at by the soil survey. It is evident that the chlorosis of the pineapples observed on certain plantations is caused by an excessive amount of calcium carbonate in the soil. Experiments show that additions of calcium carbonate to soils that produce healthy plants cause these soils to produce chlorotic plants. Soils unusually rich in humus and organic matter require a large amount of carbonate of lime to cause them to produce chlorotic plants. Soils of this latter type do not exist in Porto. Rico to our present knowledge.

No attempt was made to find by pot experiments the smallest amount of calcium carbonate in.soils that would cause this chlorosis, since the analyses of the different pineapple soils found actually producing chlorotic plants show this more accurately than could be dotermined by pot experiments. In reviewing the analyses it will be seen that the highest content of calcium carbonate found in any soil producing healthy plants was 1.15 per cent. The lowest content of calcium carbonate found in any of the soils producing chlorotic plants was about 2 per cent. This was a loose sandy soil. Thus, for sandy soils, a content of 2 per cent of calcium carbonate renders them unfit for pineapples. Possibly a sandy soil containing 2 per cent of carbonate of lime and at the same time a good content of humus might produce healthy plants, but in general it can be safely said that sandy soils containing 2 per cent or more of calcium carbonate are unfitted for pineapples. The danger limit for loamy soils may be a trifle higher. The only loamy soil which was found producing chlorotic plants contained 4.62 per cent of calcium carbonate.

[Bull. 11] 
Different varieties of pineapples may vary somewhat in their sensitiveness to lime, but, as the Cabezona variety has been found showing chlorosis in a soil containing 3.30 per cent of calcium carbonate, this variety can not be considered more resistant than the Red Spanish. In only one case were the native varieties Caraqueña and Pan de Azucar found growing in a calcareous soil. This soil contained 21.77 per cent of calcium carbonate and the plants were strongly chlorotic. At present the Cabezona and Red Spanish are the only varieties of pineapples grown commercially in Porto Rico. It is possible that the Smooth Cayenne and some other varieties which have poorer shipping qualities might prove more resistant.

From the foregoing it appears that pineapples are almost as sensitive to calcium carbonate as lupines, which will not grow in a soil containing 2 per cent of calcium carbonate.

Since calcareous soils contuining a large amount of humus do not produce chlorotic plants, it might be thought that by raising the humus content of these soils they could be made to grow pineapples. In fact, applications of barnyard manure were found to produce some improvement in the plants. For most of these calcareous soils, however, it is impracticable to raise the humus content sufficiently high to render them suitable for pineapples. Probably heavy applications of barnyard manure or other organic matter to soils containing but 2 per cent of culcium carbonate would much improve the condition of the plants.

In the following pages is described another means of overcoming the disturbances in the plant associated with the chlorosis, and of restoring the normal green (chlorophyll) to the leaves. Nevertheless, it is improbable that this treatment will be commercially successful. In the present condition of the pineapple industry in Porto Rico, where there are still large unplanted areas suitable for pineapples, it is not advisable to plant on soils which require extra, and fairly expensive, treatment to produce a crop. It is better to abandon the plantings of pineapples on these calcareous soils and put in crops which are adapted to this type of soil.

The calcareous sands near the sea are well adapted to coconuts. On the sandy soils which do not contain an excessive amount of carbonate of lime, gandules and citrus trees are found growing well. Tobacco does well on the calcareous soils which are not too near the sea. It is advisable to plant these calcareous soils to one of the above crops rather than to pineapples which will require extra treatment to yield a erop.

[Bull. 11] 


\section{INVESTIGATIONS OF THE CHLOROSIS.}

\section{PREVIOUS WORK ON LIME-INDUCED CHLOROSIS.}

Although it has never before been shown that pineapples are intolerant of calcium carbonate and that chlorosis is induced in this plant by the excessive amount of lime, ithas been observed that many other species of plants growing on calcaroous soils show chlorosis. The amount of lime that plants will tolerate varies greatly with the different species and also with the different varieties of the same species. The chlorosis of grapevines on certain marly soils of France and Germany is probably the best known example of lime-induced chlorosis. Some American phyloxera-resistant stocks show chlorosis on soils containing as little as 5 per cent of carbonate of lime; other American stocks are much more resistant, while certain native French stocks and hybrids show no chlorosis on soils containing 50 to 70 per cent of lime carbonate. ${ }^{1}$

Yellow and blue lupines and seradella are very sensitive to lime, only tolerating about 2 per cent of calcium carbonate in the soil, and their growth is greatly depressed in soils containing as little as 1 per cent. $^{2}$ The varieties of lupines, Lupinus mutabitis, $L$. albus and $L$. nanus, however, are lime-loving plants and resist even 30 per cent of lime carbonate. ${ }^{3}$

A chlorosis of pear trees growing on a strongly calcareous soil of the Isle of Sainte-Anne is reported by Dauthenay. ${ }^{4}$ In Hertfordshire, England, an orchard of various fruit trees planted on a soil overlying a chalk formation was strongly affected with chlorosis. The surface soil contained 13.53 per cent of lime carbonate. Pears, peaches, plums, nectarines, apricots, and cherries were among the trees affected. ${ }^{5}$ Hilgard reports a chlorosis of citrus trees growing on a marly subsoil containing 22 to 39 per cent of lime carbonate. ${ }^{6}$

The chlorosis of many ornamental and uncultivated plants growing on calcareous soils has also been observed. Sachs ${ }^{7}$ reports the chlorosis of a large number of plants growing in the garden of the Botanical Institute in Würzburg. The soil of this garden he describes as strongly calcareous.

Aside from the observations of the chlorosis of plants on calcareous soils there is an extensive literature on the adaptability of various plants to calcareous soils.

1 The amount of lime that the different varieties of grapevines will tolerate is given by J. M. Guillon and O. Brunaud. Rev. Vit., 20 (1903), p. 535.

${ }^{2}$ Landw. Jahrb., 30 (1901), Sup. 2, p. 61.

3 J. A.C. Roux. Traité des Rapports des Plantes avec le sol et de la Chlorose Végétale. Montpellier and Paris, 1900, p. 132.

4 H. Dauthenay. Rev. Hort. [Paris], 73 (1901), p. 50.

${ }^{5}$ R. L. Castle. Gard. Chron., 3. Ser., 25 (1899), No. 652, p. 405; 26 (1899), No. 653, p. 4.

6 California Sta. Circ. 27.

7 J. Sachs. Arb. Bot. Inst. Würzburg, 3 (1888), p. 433.

[Bull. 11] 
Hilgard, ${ }^{1}$ Hoffmann, ${ }^{2}$ Braungart, ${ }^{3}$ Roux,${ }^{4}$ and a great many others have observed that certain species of plants fail to make a normal growth on calcareous soils or refuse to grow at all. On the other hand there are certain plants which only reach their fullest development on soils that are rich in calcium carbonate.

Although it is so well known that certain plants become chlorotic when grown on calcareous soils, the way in which the lime acts in producing the chlorosis is not well understood. As long ago as 1843 Eusébe Gris showed that by treatment with ferrous sulphate chlorotic plants become green. Nuch later Sachs ${ }^{5}$ treated many chlorotic plants successfully with ferrous sulphate. A great deal of work has been done in France and Germany on the treatment of chlorotic grapevines with ferrous sulphate and other compounds of iron. ${ }^{6}$ These treatments where they have not completely restored the normal green to the leaves have markedly diminished the chlorosis. Hiltner ${ }^{7}$ has restored the green color to chlorotic lupines growing on a strongly calcareous soil.

That the effectiveness of the ferrous sulphate in overcoming the chlorosis is due merely to the iron was well shown by Guillon, ${ }^{8}$ who treated chlorotic grapevines with ferrous sulphate, sulphuric acid, sodium sulphate, and with the tannate, malate, and citrate of iron. Only the iron compounds were effective. Hiltner ${ }^{7}$ in a similar manner confirmed this in his treatment of lupines.

The opinion of those who have treated successfully the chlorotic plants with ferrous sulphate and ferric chlorid is, in general, that the chlorosis of the plants is caused by a lack of iron in the plant, the plant being unable to take up the necessary amount of iron in calcareous soils. However, comparative analyses made of chlorotic and green leaves and wood of the grapevine by Schulze ${ }^{9}$ show that the healthy plant contains much more potash than the chlorotic plant. Mach and Kurmann ${ }^{10}$ obtained similar results. Others, therefore, including Sorauer ${ }^{11}$ and Euler, ${ }^{12}$ have the opinion that the chlorosis is largely induced by a lack of potash.

1 E. W. IIilgard. Soils. New York, 1906. Proc. Soc. Prom. Agr. Sci., 7 (1886), p. 32; Forsch. Geb. Agr. Phys., 10 (1888), p. 185.

2 H. Hoffmann. Landw. Vers.Stat.;13(1871), p. 269.

3 R. Braungart. Jour. Landw., 28 (1880), p. 155.

4J. A.C. Roux. Traité des Rapports des Plantes avec le sol et de la Chlorose Végétale. Montpellier and Paris, 1900.

5 Loc. cit.

6 Luedecke. Ztschr. Landw. Ver. Grossherzogthums Hessen, 62 (1892), No.41, p. 333; 63 (1893), No. 2, p. 9. A. Bernard, Prog. Agr. et Vit., 18 (1892), pp. 36-42. J. M. Guillon, Prog. Agr. et Vit., 26 (1896), pp. 606-608.

A. Menudier, Jour. Agr. Prat., 60 (1896), II, pp. 157, 158. J. Dufour, Ber. Schweiz. Bot. Gesell., 1892, No.

2, pp. $44-46$.

7 L. Hiltner. Prakt. Bl. Pflanzenbau u. Pflanzenschutz, n. ser., 7 (1909), Nos. 2, 3, 5.

8 J. M. Guilion. Prog. Agr. et Vit., 23 (1895), p. 653.

9 E. Schulze. Centbl. Agr. Chem., 2 (1872), p. 99.

10 Centbl. Agr. Chem., 1877, p. 58.

II Paul Sorauer. Handbuch der Pflanzenkrankheiten, Berlin, 1909; 3. ed., vol. 1; p: 310.

12 H. Euler. Grundlagen und Ergebnisse der Pflanzenchemle. Braunschweig, 1909, pt. 3, p. 153.

[Bull. 11] 
IIollrung ${ }^{1}$ is of the opinion that the alkalinity of calcareous soils is one of the principal causes of the chlorosis of grapevines, as they seem to grow best on slightly acid soils. $\mathrm{M}_{\mathrm{Col}}{ }^{2}$ is of the opinion that the chlorosis of grapes is largely caused by the physical condition of the soil.

From the previous work on chlorosis it is then apparent that certain plants growing on calcareous soils become chlorotic, and that treatment with certain iron salts is more or less effective in ameliorating the chlorotic condition. As to just how the carbonate of lime acts in causing the chlorosis there is some difference of opinion.

To ascertain if possible how the lime disturbs the physiology of pineapples and induces the chlorosis the following investigations were made.

\section{EFFECT OF SOIL ALKALINITY AND ASSIMILABLE LIME IN CAUSING CHLOROSIS.}

Chemically calcareous soils differ chiefly from ordinary soils in having an alkaline reaction and in containing a large amount of easily assimilable lime. If the mere alkalinity of the calcareous soils were the causative feature it would be expected that soils rendered alkaline with sodium carbonate would also produce chlorotic plants. If the large amount of assimilable lime causes the chlorosis it would be expected that soils treated with calcium sulphate would produce chlorotic plants. To determine whether the chlorosis is caused either by the alkalinity or the large amount of assimilable lime, pot experiments were carried out.

The experiments were carried out after the manner described on page 21 except that the pots receiving sodium carbonate were kept in the glass house to prevent loss of the alkali by leaching.

In the experiment with sodium carbonate the soil used was No. 213. Five check pots received nothing, five received sufficient anhydrous sodium carbonate to give the soil a content of 0.01 per cent, five received sodium carbonate to 0.05 per cent, and five sodium carbonate to 0.10 per cent of the weight of soil. The condition of the plants at the end of 10 months is given in the following table:

Results of experiment in which sodium carbonate was added to sandy soil.

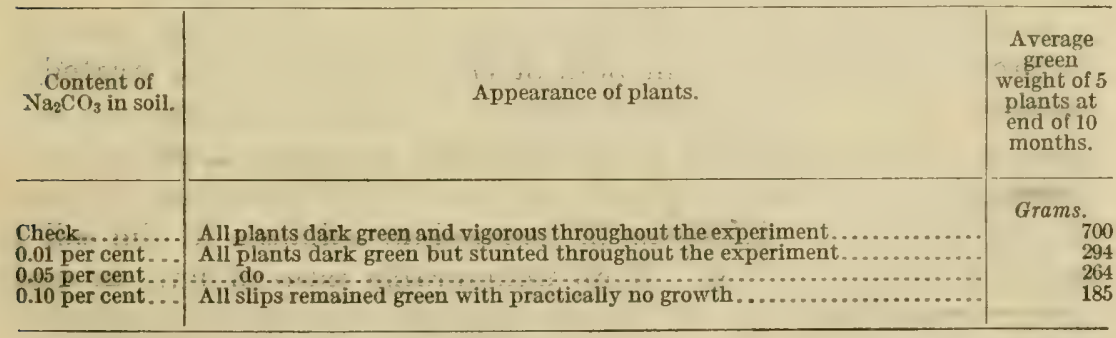

1 M. Hollrung. Landw. Jahrb., 37 (1908), pp. 497-616.

2 E. Molz. Centbl. Bakt. [etc.], 2. Abt., 19 (1907), Nos. 13-15, p. 461; 16-18, p. 563; 21-23, p. 715; 24-25, p. $788 ; 20$ (1907), Nos. $1-3$, p. $71 ;$ i-5, p. 126.

[Bull. 11] 
The results in brief were: The check plants made a good green growth; the plants in the pots with sodium carbonate were greatly depressed in growth; those in the pots with 0.10 per cent of $\mathrm{Na}_{2} \mathrm{CO}_{3}$ making scarcely any growth; but all plants maintained a good dark green color.

It is, then, evident that it is not alone the soil alkalinity that causes the chlorosis. While the alkalinity produced by 0.01 per cent of $\mathrm{Na}_{2} \mathrm{CO}_{3}$ is sufficient to greatly depress the growth of the plant, it disturbs the nutrition in a very different manner from $\mathrm{CaCO}_{3}$, as it apparently has no effect on the formation of chlorophyll.

In the experiment with calcium sulphate, or gypsum, soil No. 18 was used. Five check pots received no gypsum, five pots received sufficient gypsum to give the soil a content of 5 per cent $\mathrm{CaO}$, five gypsum to a content of 10 per cent $\mathrm{CaO}$ and five gypsum to a content of 15 per cent $\mathrm{CaO}$. The results are given in the following table:

Results of experiment in which gypsum uas added to loamy soil.

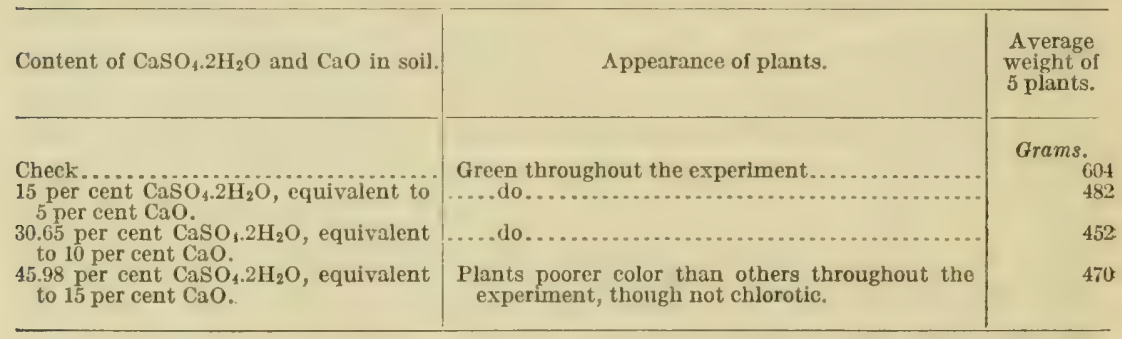

It appears that while the heavy application of gypsum depressed the growth, like the sodium carbonate it failed to produce the chlorosis.

Since, then, it is neither the alkalinity alone nor the large amount of assimilable lime that induces the chlorosis, it would seem that the chlorosis is induced by both these factors working together. These factors may act directly on the plant or indirectly, by their effect on some of the nutrients contained in the soil.

\section{TREATMENT OF CHLOROTIC PLANTS WITH IRON AND OTHER SALTS.}

A number of experiments were made to overcome the chlorosis. Chlorotic plants growing in pots of calcareous soil were treated in various ways. Watering with Knop's nutrient solution was ineffective. This was partly to be expected, as heavy applications of nitrogen, potash, and phosphoric acid were found unavailing in checking the chlorosis. Additions of magnesium sulphate to the soil at intervals gave no result. If an unfavorable ratio of lime to magnesium were the cause of the trouble, this treatment should have proven beneficial.

[Bull. 11] 
Treatment with iron salts, however, was signally effective in restoring the normal green color to the leaves. At first, 2 per cent solutions of ferrous sulphate were added to the soil in which chlorotic plants were growing without improving the condition of the plants at all. Crystals of ferrous sulphate were then put in the soil, either touching the roots or in their immediate vicinity. Three weeks after the application the treated plants had improved considerably in color, one month later the treated plants were practically a normal green and had increased considerably in growth. The untreated chlorotic plants which served as checks remained practically white and without growth. (Pl. II, fig. 2.)

Chlorotic plants were also treated by brushing the leaves with a 2 per cent solution of ferrous sulphate, a 2 per cent solution of ferric chlorid, and a 2 per cent solution of sulphuric acid. The brushing was repeated four times, at intervals of 10 days. The plants treated with sulphuric acid showed no improvement, while those treated with the iron salts were considerably greener two weeks after the first brushing, and three weeks later were of a normal green. The facts that sulphuric acid was ineffective and that ferric chlorid and ferrous sulphate were equally effective in curing the chlorosis indicate that the action is to be attributed to the iron alone and not to the sulphate radical nor to the acidity of the salts.

One plant, the leaves of which were almost waxy white, except for a few brown spots where decay was starting, was treated by dropping a crystal of ferrous sulphate in the heart. The center leaves were burnt out by the acidity of the salt, but the other leaves became green and a vigorous green shoot was sent out.

The effectiveness of brushing with iron salts depends upon the solution penetrating the epidermis of the leaves. Leaves which were burnt by the strength of the solution became green much more rapidly than uninjured leaves. Leaves which were pricked previous to the brushing, so that the solution could penetrate readily, became green sooner than unpricked leaves.

While the above treatments were signally effective in restoring the normal color and growth to plants, one treatment does not suffice for the life of the plant. Three or four months after the restoration of the green color, or chlorophyll, the new leaves commence to show chlorosis, and the whole plant gradually becomes chlorotic again. A renewed treatment with iron is again effective.

To grow pineapples on strongly calcareous soils would necessitate repeatedly spraying the plants with ferrous sulphate, as applications of ferrous sulphate to the soil are unavailing. It is possible that on calcareous soils, containing from 2 to 5 per cent of calcium carbonate, an application of ferrous sulphate to the soil might be efficacious, as [Bull. 11] 
with a smaller amount of lime the iron would not be rendered unavailable so quickly.

It is very doubtful if treatment with iron salts would render pineapple growing on calcareous soils commercially successful, as the repeated treatments with iron would be expensive and the crop would not be equal to that secured from soils naturally adapted to pineapples.

\section{ASH CONTENT OF GREEN AND CHLOROTIC LEAVES.}

An examination was made of the ash content of green and chlorotic leares. Since the chlorosis is evidently caused by a disturbance in the mineral nutrition of the plant, it was thought that the difference between the ash content of green and chlorotic leaves ought to make evident in what the disturbance consists. As the ash varies considerably with the age of the plant, only plants of the same age were taken for the comparative analyses.

The analyses were made according to the official methods of the Association of (Oflicial Agricultural Chemists for plant ashes, with two exceptions. As the content of lime in all the ashes far exceeds that of phosphoric acid, no addition of calcium acetate was made previous to the ignition, which took place over a very low flame. Check analyses were run on samples ignited with and without calcium acetate and it was found that there was no loss of phosphoric acid in the ignition without calcium acetate and that the lime could be determined more accurately without the acetate addition. The determination of potash was made according to the method given by Königr ${ }^{1}$; as for the determination of potash alone in these ashes, this method was more accurate.

The plants from experiments I, II, and III (see pp. 23-25) were analyzed at the close of the experiments. As the experiments were run in series of five, equal samples of the dried substance of each of the five plants were combined to make a composite sample for the analysis. The analytical results in the table below are thus an arerage of the five plants grown under like conditions. All the plants in this table were $10 \mathrm{months}$ old and the plants in each experiment had received the same amount of fertilizer. The only factor tending to create a difference in the respective ashes was the amount of calcium carbonate in the soil.

In the table there are three series of comparative analyses-plants grown in a sandy soil, in a loamy soil, and in a soil rich in humus. In each series there are three analyses-plants grown in the soil without calcium carbonate, in the soil plus 30 per cent of calcium carbonate, and in the soil plus 50 per cent of calcium carbonate.

I J. König. Die Untersuchung landwirtschaftlich und gewerblich wichtiger Stoffe. Berlin, 1906, 3. ed., pp. 29,30 .

[Bull, 11] 
The percentages of lime, magnesia, phosphoric acid, potash, and iron, in the carbon-free ash are given and also the percentages of these constituents and nitrogen in the dry substance of the plant.

Analyses of the ash of plants grown on sandy, loamy, and humus soils.

ANALYSIS OF CARBON-FREE ASH.

\begin{tabular}{|c|c|c|c|c|c|c|c|c|}
\hline $\begin{array}{l}\text { Experiment from which } \\
\text { plants were taken. }\end{array}$ & $\begin{array}{l}\mathrm{CaCO}_{3} \\
\text { in soil. }\end{array}$ & $\begin{array}{l}\text { Appearance } \\
\text { of leaves. }\end{array}$ & 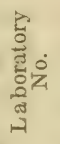 & 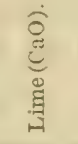 & 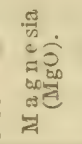 & 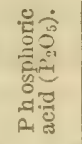 & 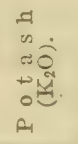 & 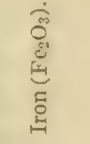 \\
\hline $\begin{array}{l}\text { I (sandy soil) ........... } \\
\text { II (loamy soil) .......... } \\
\text { III (soil rich in humus) ... }\end{array}$ & $\left\{\begin{array}{r}\text { Per cent. } \\
\text { None. } \\
30 \\
50 \\
\text { None. } \\
30 \\
50 \\
\text { None. } \\
30 \\
50\end{array}\right.$ & 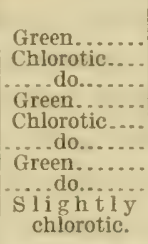 & $\begin{array}{l}342 \\
343 \\
344 \\
345 \\
346 \\
347 \\
337 \\
338 \\
339\end{array}$ & $\begin{array}{r}\text { Per ct. } \\
11.54 \\
13.00 \\
16.42 \\
8.80 \\
13.38 \\
14.36 \\
9.76 \\
9.80 \\
11.10\end{array}$ & $\begin{array}{r}\text { Per ct. } \\
8.68 \\
7.09 \\
8.14 \\
9.60 \\
7.99 \\
6.95 \\
5.60 \\
4.89 \\
4.73\end{array}$ & $\begin{array}{r}\text { Per ct. } \\
5.21 \\
5.42 \\
4.86 \\
4.64 \\
4.74 \\
4.04 \\
6.49 \\
6.65 \\
6.28\end{array}$ & $\begin{array}{r}\text { Per } c t . \\
48.22 \\
55.20 . \\
48.10 \\
44.28 \\
38.62 \\
42.61 \\
55.94 \\
56.95 \\
29.37\end{array}$ & $\begin{array}{r}\text { Per ct. } \\
4.65 \\
4.22 \\
1.86 \\
2.74 \\
2.28 \\
2.20 \\
3.62 \\
6.87 \\
3.02\end{array}$ \\
\hline
\end{tabular}

ASH CONSTITUENTS IN DRY SUBSTANCE OF PLANT.

\begin{tabular}{|c|c|c|c|c|c|c|c|c|c|c|}
\hline $\begin{array}{l}\text { Experiment from which } \\
\text { plants were taken. }\end{array}$ & $\begin{array}{l}\mathrm{C}_{2} \mathrm{CO}_{3} \\
\text { in soil. }\end{array}$ & $\begin{array}{l}\text { Appearance } \\
\text { of leaves. }\end{array}$ & 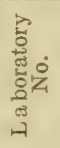 & 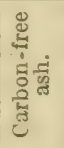 & 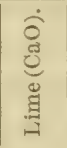 & 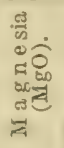 & 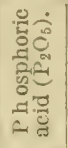 & 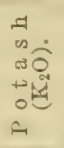 & 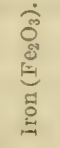 & 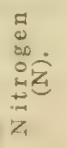 \\
\hline $\begin{array}{l}\text { I (sandy soil) ........ } \\
\text { II (loamy soil) ....... } \\
\text { III (soil rich in humus }\end{array}$ & $\left\{\begin{array}{r}\text { Percent. } \\
\text { Vone. } \\
30 \\
50 \\
\text { None. } \\
30 \\
50 \\
\text { None. } \\
30 \\
50\end{array}\right.$ & $\begin{array}{l}\text { Green...... } \\
\text { Chlorotic... } \\
\text { Green...... } \\
\text { Chlorotic... } \\
\text { Greedo....... } \\
\text { Green.... } \\
\text { Slightly } \\
\text { chlorotic. }\end{array}$ & $\begin{array}{l}342 \\
3 \pm 3 \\
3+4 \\
3 \pm 5 \\
3+6 \\
3+7 \\
337 \\
338 \\
339\end{array}$ & $\begin{array}{l}\text { P.ct. } \\
6.19 \\
6.43 \\
9.11 \\
5.93 \\
6.08 \\
7.45 \\
6.76 \\
6.68 \\
8.11\end{array}$ & $\begin{array}{r}P . c t . \\
0.71 \\
.84 \\
1.50 \\
.52 \\
.81 \\
1.07 \\
.66 \\
.65 \\
.90\end{array}$ & $\begin{array}{l}P . c t . \\
0.54 \\
.46 \\
.74 \\
.57 \\
.49 \\
.52 \\
.38 \\
.33 \\
.38\end{array}$ & $\begin{array}{c}P . c t . \\
0.32 \\
.35 \\
.44 \\
.28 \\
.29 \\
.30 \\
.44 \\
.44 \\
.51\end{array} \mid$ & $\begin{array}{l}\text { P.ct. } \\
2.99 \\
3.55 \\
4.38 \\
2.63 \\
2.35 \\
3.18 \\
3.78 \\
3.83 \\
2.38\end{array}$ & $\begin{array}{l}\text { P.ct. } \\
0.29 \\
.27 \\
.17 \\
.16 \\
.14 \\
.16 \\
.21 \\
.46 \\
.24\end{array}$ & $\begin{array}{r}\text { P.ct. } \\
0.67 \\
.55 \\
.55 \\
.75 \\
.58 \\
.60 \\
.72 \\
.67 \\
.69\end{array}$ \\
\hline
\end{tabular}

It will be seen that the addition of calcium carlomate to the sindy and loamy soils, inducing chlorosis, had the effect of increasing the percentage of lime in the plant ash and of diminishing the percentages of iron. The percentage of magnesia as a rule diminishes, although not with the same regularity, while the phosphoric acid shows no regular increase or diminution. In the soil rich in humus the addition of 30 per cent of calcium carbonate had no effect upon the plant ash, and it will be remembered that it also had no effect in inducing the chlorosis. The addition of 50 per cent of calcium carbonate to this soil, however, induced a slight chlorosis, and affected the plant ash, in the same way, although to a less degree as did smaller additions of calcium carbonate to the sandy and loamy soils.

In regard to the percentages of the various mineral constituents in the dried substance of the plant, it will be seen that wherever chlorosis was induced the addition of calcium carbonate to the soil

[Bull. 11] 
had the effect of increasing the percentage of total ash in the plant, of increasing the lime, and of diminishing the nitrogen. Between the chlorotic and green plants there were no regular differences in the percentages of phosphoric acid, iron, and magnesia in the dried substance.

From a consideration of these analyses alone it appears, by a process of elimination, that the chlorosis is in some way dependent upon the content of lime or iron in the ash or upon the content of ash, lime, or nitrogen in the dried substance.

In fields of chlorotic plants growing on calcareous soils there were always certain individual plants that maintained a green color longer than the others. These plants eventually became chlorotic, but it was thought that possibly the ash content of the plants, which had not yet become chlorotic, might show some regular differences from the ash of plants that were already chlorotic. In the table below such comparative analyses are given. The first four analyses are of plants grown on a soil containing 3.30 per cent of calcium carbonate. The next two analyses are of plants grown on a soil containing 79 per cent of $\mathrm{CaCO}_{3}$, and the last two of plants grown on a soil containing 33 per cent of $\mathrm{CaCO}_{3}$. The analyses are to be compared by twos, as in each case the chlorotic plant and check plant were grown under the same conditions.

Analyses of the ash of chlorotic and green plants from calcareous soils.

\begin{tabular}{|c|c|c|c|c|c|c|c|c|c|c|c|c|c|c|}
\hline \multirow[b]{2}{*}{$\begin{array}{l}\text { Descripticn } \\
\text { of plant. }\end{array}$} & \multirow[b]{2}{*}{$\begin{array}{l}\text { Appearance } \\
\text { of leaves. }\end{array}$} & \multirow[b]{2}{*}{ 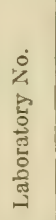 } & \multicolumn{5}{|c|}{ Analysis of carbon-free ash. } & \multicolumn{7}{|c|}{$\begin{array}{l}\text { Ash constituents in dry substance } \\
\text { of plant. }\end{array}$} \\
\hline & & & 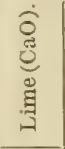 & 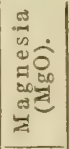 & $\mid \begin{array}{ll}0 & 0 \\
0 & 0 \\
0 & 0 \\
0 & 0 \\
0 & 0 \\
0 & 0 \\
0 & 0 \\
0 & 0\end{array}$ & $\begin{array}{l}f \\
\infty \\
\infty \\
\omega \\
\omega \\
0 \\
\infty\end{array}$ & 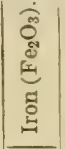 & 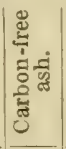 & 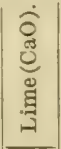 & 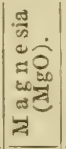 & 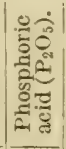 & $\left|\begin{array}{l}a \\
\infty \\
\omega \\
\omega \\
\omega \\
0 \\
0 \\
0 \\
\infty\end{array}\right|$ & 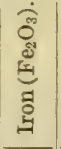 & 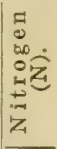 \\
\hline $\begin{array}{l}\text { Large Cabezo- } \\
\text { na, } 18 \text { mos. } \\
\text { old. }\end{array}$ & Green. & 237 & $\begin{array}{l}P . c t . \\
27.33\end{array}$ & $\begin{array}{r}P . c t \\
9.12\end{array}$ & $\begin{array}{r}P . c t \\
5.89\end{array}$ & $\begin{array}{l}P . c t \text {. } \\
33.44\end{array}$ & P.ct. & $\begin{array}{l}P . c t \\
6.00\end{array}$ & $\begin{array}{r}P . c t \\
1.64\end{array}$ & $\begin{array}{c}P . c t \\
0.55\end{array}$ & $\begin{array}{l}P . c t \\
0.35\end{array}$ & $\begin{array}{r}P . c t \\
2.01\end{array}$ & $\begin{array}{r}P . c t \text {. } \\
0.07\end{array}$ & $\begin{array}{l}\text { P.ct. } \\
0.90\end{array}$ \\
\hline $\begin{array}{l}\text { Do....... } \\
\text { Small Cabezo- } \\
\text { na, } 18 \text { mos. } \\
\text { old. }\end{array}$ & $\begin{array}{l}\text { Chlor } \\
\text { Green }\end{array}$ & $\begin{array}{l}238 \\
233 \mathrm{a}\end{array}$ & $\begin{array}{l}26.18 \\
23.16\end{array}$ & $\begin{array}{r}14.19 \\
6.70\end{array}$ & $\begin{array}{l}8.53 \\
8.54\end{array}$ & 43.72 & .49 & $\begin{array}{l}5.33 \\
5.81\end{array}$ & $\begin{array}{l}1.40 \\
1.35\end{array}$ & $\begin{array}{l}.76 \\
.39\end{array}$ & $\begin{array}{l}.45 \\
.50\end{array}$ & 2.54 & .03 & .71 \\
\hline $\begin{array}{l}\text { Do....... } \\
\text { Red Spanish, } \\
24 \text { mos. old. }\end{array}$ & $\begin{array}{l}\text { Chlo } \\
\text { Gree }\end{array}$ & $\begin{array}{l}233 d \\
196\end{array}$ & $\begin{array}{l}24.00 \\
29.40\end{array}$ & $\begin{array}{l}10.35 \\
12.55\end{array}$ & $\begin{array}{l}5.66 \\
4.42\end{array}$ & $\begin{array}{l}29.65 \\
13.05\end{array}$ & .47 & $\begin{array}{l}7.70 \\
6.28\end{array}$ & $\begin{array}{l}1.85 \\
1.85\end{array}$ & $\begin{array}{l}.80 \\
.79\end{array}$ & $\begin{array}{r}.44 \\
.28\end{array}$ & $\begin{array}{r}2.28 \\
.82\end{array}$ & .04 & $\begin{array}{l}.76 \\
.91\end{array}$ \\
\hline Red Spanish, & $\begin{array}{l}\text { Chloroti } \\
\text { Green.. }\end{array}$ & $\begin{array}{l}195 \\
104\end{array}$ & $\begin{array}{l}29.45 \\
23.37\end{array}$ & \begin{tabular}{r}
9.83 \\
\hdashline... \\
\end{tabular} & $\begin{array}{l}3.45 \\
4.93\end{array}$ & $\begin{array}{l}19.78 \\
35.45\end{array}$ & .43 & $\begin{array}{l}7.10 \\
6.56\end{array}$ & $\begin{array}{l}2.09 \\
1.53\end{array}$ & .70 & $\begin{array}{r}.25 \\
.32\end{array}$ & $\begin{array}{l}1.39 \\
2.33\end{array}$ & .03 & $\begin{array}{r}.66 \\
1.47\end{array}$ \\
\hline & Chlorotic & 103 & 28.17 & & 3.46 & 33.64 & .55 & 7.81 & 2.2 & & .27 & 2.63 & .04 & .88 \\
\hline
\end{tabular}

It will be scen from the table that there are no differences between the analyses of the green and chlorotic plants that are sustained in all four cases. The nitrogen content of the green and chlorotic plants is in one case equal but in the other three cases in this table, as well as in all the other analyses made, the chlorotic plants contain much less nitrogen than the corresponding green plants.

[Bull. 11] 
Considering all the analyses together, it will be seen that the ash of these plants grown on calcareous soils differs from the ash of plants grown on noncalcareous soils chiefly in containing a larger amount of lime and a smaller amount of iron. ${ }^{1}$

While there were no difierences between the chlorotic and green plants reported in the table it should be borne in mind that the green 1 plants were exceptional in that they resisted the chlorosis longer than the average plant, also, that while these plants were green, they were not normally developed and that this class of plants eventually became chlorotic (p. 36).

To see whether the large amount of lime in the ash is the sole cause of the chlorosis analyses were made of plants which were grown on noncalcareous soils that had received a heavy application of lime. The plants were grown on small plats of a clay loam soil, 40 plants to the plat. The check plat received no lime; the second plat, lime at the rate of 3,400 pounds of calcium oxid per acre in the form of burnt lime; and the third plat, the same amount of calcium oxid per acre but applied in the form of gypsum and burnt lime together. The growth of the plants in the limed plats was depressed, but none of the plants ever showed chlorosis. The plants were 16 months old when analyzed. In the following table are given the analyses of plants from each of the three plats:

\section{Analyses of the ash of plants grown on noncalcareous soils which had received heavy} applications of lime.

\begin{tabular}{|c|c|c|c|c|c|c|c|c|c|c|c|c|c|c|}
\hline \multirow[b]{2}{*}{$\begin{array}{l}\text { Quantity of lime } \\
\text { per acre added } \\
\text { to soil. }\end{array}$} & \multirow{2}{*}{ 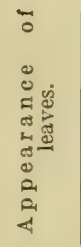 } & \multirow[b]{2}{*}{ 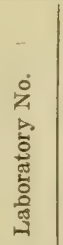 } & \multicolumn{5}{|c|}{ Analysis of carbon-free ash. } & \multicolumn{7}{|c|}{$\begin{array}{l}\text { Ash constituents in dry substance of } \\
\text { plant. }\end{array}$} \\
\hline & & & 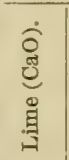 & 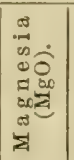 & 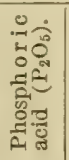 & 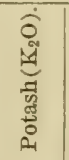 & 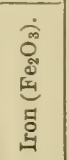 & 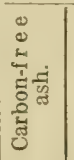 & 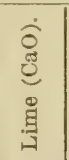 & 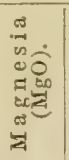 & 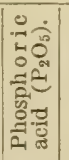 & 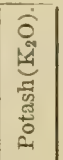 & 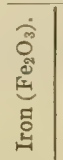 & 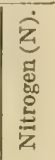 \\
\hline 3,400 los. $\mathrm{CaO}$ & Green. & 268 & $\begin{array}{l}\text { P.ct. } \\
12.00\end{array}$ & $\begin{array}{l}\text { P. ct. } \\
19.40\end{array}$ & $\begin{array}{c}P_{\dot{0}} c t . \\
5.96\end{array}$ & $\begin{array}{l}\text { P.ct. } \\
53.04\end{array}$ & $\begin{array}{c}P . c t . \\
7.36\end{array}$ & $\begin{array}{c}P . c t . \\
3.19\end{array} \mid$ & $\begin{array}{r}P . c t . \\
0.38\end{array}$ & $\begin{array}{r}P . c t . \\
0.62\end{array}$ & $\begin{array}{l}P . c t . \\
0.19\end{array}$ & $\begin{array}{l}P . \dot{c} t . \\
1.69\end{array}$ & $\begin{array}{c}P . c t \\
0.24\end{array}$ & $\begin{array}{l}\text { P. } c t \text {. } \\
0.93\end{array}$ \\
\hline $\begin{array}{l}\text { from CaO } \ldots . . . \\
3,400 \mathrm{lbs} . \mathrm{CaO} \\
\text { from CaO and } \\
\mathrm{CaSO} . . . . . . .\end{array}$ & ...do... & 266 & 27.60 & 20.79 & 6.53 & 27.33 & 2.82 & 3.23 & .89 & .67 & .21 & .71 & .18 & .79 \\
\hline
\end{tabular}

It will be seen that the plants grown on the soils to which lime was applied contained more lime in the ash and dried substance than the check plant and less potash and iron. While the content of iron in the plants grown on the limed plats is much less than that of the check plant it is nevertheless much greater than that of the plants reported in the preceding table ( $p .36)$. The nitrogen is practically. the same in all three plants.

\footnotetext{
1 The analyses in the above table show a higher percentage of lime and a lower percentage of iron than any of the analyses reported by J. C. Brünnich. Queensland Dept. Agr. Rpt. 1903-4, p. 76.
}

[Bull. 11] 
Comparing the analyses in the last table with those in the preceding table it appears that the green plants of the last table contained as much lime and as little potash as the plants grown under conditions which induced chlorosis, but differed in containing much more iron.

Analyses were also made of chlorotic plants and of plants that were once chlorotic but that had become green by treatment with ferrous sulphate. These plants were all grown in soil containing 33 per cent of calcium carbonate and, previous to the treatment with iron, were all equal in size and equally chlorotic. Two months after the plants treated with ferrous sulphate had become green all the plants were cut and analyzed.

The results of the analyses are given in the table below. The first two analyses are to be compared with each other and the final three with each other, as the treatments with ferrous sulphate were carried out at different times in these two cases.

Analyses of the ash of treated and untreated chlorotic plants.

\begin{tabular}{|c|c|c|c|c|c|c|c|c|c|c|c|c|c|c|}
\hline \multirow[b]{2}{*}{$\begin{array}{l}\text { Treatment of } \\
\text { plants. }\end{array}$} & \multirow{2}{*}{ 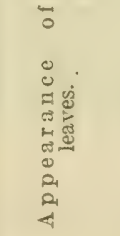 } & \multirow[b]{2}{*}{ 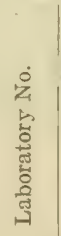 } & \multicolumn{5}{|c|}{ Analysis of carbon-free ash. } & \multicolumn{7}{|c|}{$\begin{array}{l}\text { Ash constituents in dry substance of } \\
\text { plant. }\end{array}$} \\
\hline & & & 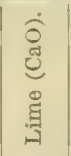 & 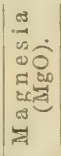 & 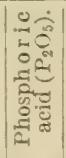 & 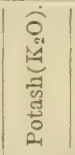 & 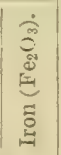 & 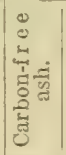 & 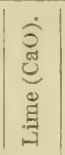 & 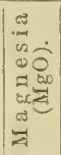 & 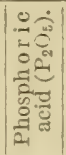 & 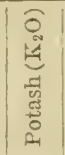 & 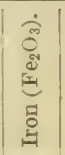 & 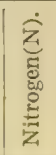 \\
\hline & Chloro & 255 & $\begin{array}{l}\text { P.ct. } \\
30.10\end{array}$ & $\mid \begin{array}{l}P . c t \\
9.18\end{array}$ & $\begin{array}{l}\text { P.ct. } \\
3.14\end{array}$ & $\mid \begin{array}{l}P . c t \\
37.69\end{array}$ & $\left|\begin{array}{c}P . c t \\
0.68\end{array}\right|$ & $\begin{array}{l}P . c t \\
5.87\end{array}$ & P.ct. & $\begin{array}{c}P . c t . \\
0.54\end{array}$ & P.ct. & $\begin{array}{l}P . c t . \\
2.21\end{array}$ & P.ct. & $P . c t$ \\
\hline $\begin{array}{l}\text { Brushed w it h } \\
\text { FeSO }_{4} \ldots \ldots \ldots \ldots \ldots\end{array}$ & Green & 254 & 20.59 & 6.09 & 4.04 & 46.25 & 1.51 & 5.63 & 1.16 & .34 & 1. .23 & 2.60 & .09 & \\
\hline $\begin{array}{l}\text { Untreated.... } \\
\text { Brnshed } \mathrm{i} \text { t } \mathrm{h}\end{array}$ & Chloro & & & 9.62 & 2.67 & 46.46 & & 6.09 & 1.34 & .59 & .16 & 2.25 & .03 & 0.79 \\
\hline & Gree & $27 \bar{\imath}$ & 24.52 & 7.25 & 2.46 & 42.09 & 1.49 & 7.30 & 1.79 & .53 & 3) .18 & 3.07 & .11 & .9 \\
\hline $\begin{array}{l}\text { FesO } 4 \text { applied to } \\
\text { roots........... }\end{array}$ & ... do & 278 & 28.76 & 9.25 & 2.90 & 37.02 & 1.01 & 6.89 & 2.10 & .68 & 3.21 & 2.55 & .07 & 1.39 \\
\hline
\end{tabular}

The ash of the plants turned green by ferrous sulphate differs from the ash of the chlorotic plants only in containing more iron. Thus it would seem from this table that the chlorosis is caused merely by a lack of iron or by a lack of iron in some active form, and that the generally lower content of potash in chlorotic plants is not the cause but a result.

Considering all the facts brought ont by the ash malyses, it would appear that the chlorosis is induced by an increased absorption of lime and a diminished absorption of iron. It is certain that the ahsorption of an unusual amount of lime is not alone sufficient to canse the chlorosis. It is possible that when an excessive amount of line is absorbed by the plant that more iron is needed than under ordinary conditions. The work of Hiltner on lupines substantiates this view. ${ }^{1}$ 
It is not felt that this conclusion can be stated with certainty from a consideration of the above ash malyses alone. If the chlorosis is caused by the combined effect of an excess of lime and a lack of iron in the plant, it would seem that there should be a definite ratio of lime to iron in the ash which would induce the chlorosis. But in the above analyses no such ratio is apparent.

It is felt that analyses of other species of plants that become chlorotic on calcareous soils are needed for confirmation, and this work is now in progress.

The lower content of nitrogen in the chlorotic plants is probably not the cause of the chlorosis but the result. The absorption of nitrogen can hardly be interfered with in calcareous soils, and in all the experiments the plants received a liberal supply of easily assimilable nitrogen. Similarly it appears that the lower content of potash found in some of the chlorotic plants of the table on page 35 is but the result of the chlorotic condition. In this table it will be seen that some chlorotic plants contain 38 per cent, 48 per cent, and 55 per cent of potash in the ash, quantities much greater than many healthy plants contain. These analyses would tend to contradict the view held by Sorauer ${ }^{1}$ and some others that the chlorosis on calcareous soils is caused by a lack of available potash.

\section{ENZYMS IN CHLOROTIC AND GREEN LEAVES.}

Woods has shown ${ }^{2}$ that under certain pathological conditions of various plants, as in the mosaic disease of the tobaceo, the attendant chlorosis seems to be caused by the presence of an excessive amount of the oxidizing enzyms, oxidases and peroxidases, in the leaves. Tests were made to see whether in the chlorosis of the pineapples the phenomenon was accompanied or caused by a like increase in the enzyms. For this purpose the content of normal green leaves in oxidases and peroxidases was compared with that of chlorotic leaves.

The method employed in comparing the different amounts of enzyms was as follows: In every case equal quantities (generally 10 grams) of the fresh leaves were triturated with sand and chloroform water in a porcelain mortar. The solution and macerated leares were then made to 500 cubic centimeters with distilled water, allowed to stand 15 hours, and passed through a dry filter. The filtrate was used in making the comparative tests; $1,2,4,6,8$, and 10 centimeters of these solutions were put in Nessler tubes, the volume of each tube made to 10 cubic centimeters with distilled water and equal quantities of neutralized hydrogen peroxid and freshly prepared 2 per cent alcoholic solution of guaiacum resin udded to each tube. At the end of 10,15 , or 20 minutes the various tubes were compared 
in regard to coloration or for the amount of guaiacum oxidized. Tubes having the same depth of coloration must contain equal quantities of the enzyms, as all the variables affecting the reaction between the enzyms and the guaiacum are fixed. In every case the amount of peroxid and guaiacum, the volume of solution, the temperature, and the time of reaction is the same. If, then, a tube to which 2 cubic centimeters of a leaf extract was added gives the same coloration as another tube containing 4 cubic centimeters of a second leaf extract, it is evident that the tubes contain equal quantities of enzyms and that the first leaf, therefore, contains twice as much of the enzyms as the second.

There is no exact quantitative method for determining the absolute amount of these enzyms, but the above method gives the comparative quantities with sufficient accuracy to show significant differences.

Tests were first made, taking samples from different leaves and parts of leaves of the same plant, in order to ascertain how great the error might be in sampling. It was found that two samples taken near together on the same leaf, or from the same relative position on leaves of similar age, gave duplicate determinations. Also samples from similarly situated leaves on different plants of the same age gave duplicate determinations. Samples taken from very old leaves differed, however, from very young ones. Also a sample taken at the base of a leaf differed slightly from one taken near the tip of the same leaf. Therefore, in all the following tests, care was used to take the samples from the same relative position on leaves of similar age.

From preliminary tests it was apparent that the quantity of oxidases in pineapple leaves is very small in comparison with the quantity of peroxidases ${ }^{1}$ and that the quantity of oxidases varies in the same proportion as the peroxidases, hence tests were only made for the peroxidases.

The leaves of the plants grown in the pot experiment described on page 21 were tested for peroxidases. ${ }^{2}$ The results are given in the following table, in which the first column gives the soil in which the plant was grown, the second the condition of the leaves in regard to chlorosis, and the third the quantity of peroxidase. The quantity of peroxidase in the leaves of the check plant is taken as 10 and the other quantities are expressed relative to this.

1 By oxidases are here meant those enzyms which blue an alcoholic guaiac solution without the addition of hydrogen peroxid, and by peroxidases, those enzyms requiring hydrogen peroxid to give the guaiac reaction.

According to Bach and Chodat and Moore and Whitley we may be dealing here with only one enzym, peroxidase; the blueing of guaiac solution without hydrogen peroxid being due to a peroxidase plus an organic peroxid.

2 Catalase was also tested for, but found present only in very small and apparently equal quantities in the green and chlorotic leaves.

[Bull. 11] 
Amount of peroxidase present in chlorotic plants grown on soils containing different percentages of calcium carbonate.

\begin{tabular}{|r|c|c|}
\hline $\begin{array}{c}\mathrm{CaCO}_{3} \text { in } \\
\text { soil. }\end{array}$ & Appearance of leaves. & $\begin{array}{c}\text { Compara. } \\
\text { tive } \\
\text { amount of } \\
\text { peroxidase. }\end{array}$ \\
\hline Per cent. \\
None. & Green.................. & \\
5 & Slightly chlorotic....... & \\
10 & $\ldots .5$ \\
13 & Chlorotic.................... & 10 \\
17 & $\ldots . .$. do................... & 5 \\
\hline
\end{tabular}

The leaves of the plants grown in pot experiments I, II, and IV (see pp. 23-25) were also tested for peroxidases. In these cases leaves were taken from two check plants, one from the largest and one from the smallest of the five grown. The results are given in the table below, the arrangement of which is the same as the preceding table.

Amount of peroxidase present in chlorotic plants grown on soils containing different percentages of calcium carbonate.

\begin{tabular}{|c|c|c|c|c|c|c|c|c|}
\hline \multicolumn{3}{|c|}{ Plants from Experiment $\mathbf{I}$. } & \multicolumn{3}{|c|}{ Plants from Experiment II. } & \multicolumn{3}{|c|}{ Plants from Experiment IV. } \\
\hline $\begin{array}{l}\mathrm{CaCO}_{3} \\
\text { in soil. }\end{array}$ & $\begin{array}{l}\text { Appearance } \\
\text { of leaves. }\end{array}$ & $\begin{array}{l}\text { Compar- } \\
\text { ative } \\
\text { amount } \\
\text { of } \\
\text { peroxi- } \\
\text { dase. }\end{array}$ & $\begin{array}{l}\mathrm{CaCO}_{3} \\
\text { in soil. }\end{array}$ & $\begin{array}{l}\text { Appearance } \\
\text { of leaves. }\end{array}$ & $\begin{array}{l}\text { Compar- } \\
\text { ative } \\
\text { amount } \\
\text { of } \\
\text { peroxi- } \\
\text { dase. }\end{array}$ & $\begin{array}{l}\mathrm{CaCO}_{3} \\
\text { in soil. }\end{array}$ & $\begin{array}{l}\text { Appearance } \\
\text { of leaves. }\end{array}$ & $\begin{array}{l}\text { Compar- } \\
\text { ative } \\
\text { amount } \\
\text { of } \\
\text { peroxi- } \\
\text { dase. }\end{array}$ \\
\hline $\begin{array}{r}\text { Per cent. } \\
\text { None. } \\
\text { None. } \\
20 \\
30 \\
40 \\
50\end{array}$ & 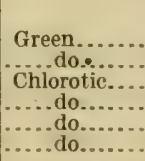 & $\begin{array}{l}10 \\
10 \\
2.5 \\
6.6 \\
3.7 \\
3\end{array}$ & $\begin{array}{r}\text { Per cent. } \\
\text { None. } \\
\text { None. } \\
20 \\
40 \\
50\end{array}$ & 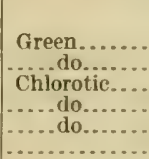 & $\begin{array}{r}10 \\
10 \\
5 \\
8 \\
4.5 \\
\end{array}$ & $\begin{array}{r}\text { Per cent. } \\
\text { None. } \\
\text { None. } \\
10 \\
30 \\
30\end{array}$ & $\begin{array}{l}\text { Green....... } \\
\text { Chlorotic.... } \\
\ldots . . \text { do....... } \\
\ldots . \text { do........ }\end{array}$ & $\begin{array}{l}10 \\
10 \\
6.6 \\
6 \\
7 \\
\ldots \ldots\end{array}$ \\
\hline
\end{tabular}

In the next table is given the peroxidase found in a chlorotic plant and in two plants that were once chlorotic, but that had become green by treatment with ferrous sulphate. The plants were all growing in a sand containing 34 per cent of calcium carbonate, and previous to the treatment with ferrous sulphate were equally chlorotic. It will be seen that although one of the plants treated with iron contains much more peroxidase than the other, they both contain more peroxidase than the chlorotic plant.

Amount of peroxidase in treated and untreated chlorotic plants.

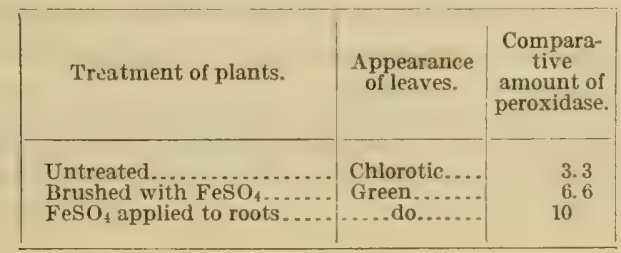

[Bull. 11] 
The results of these determinations agree in showing that green leaves of pineapple plants contain much more peroxidase than chlorotic leaves. It is apparent, then, that this chlorosis of pineapples growing in calcareous soils is caused by a different disturbance in the plant from that in those cases explained by Woods. Woods examined chlorotic leaves from many plants. Some of these yellow leaves had been punctured by aphids. The colorless portions of variegated leaves, etiolated leaves, tobacco leaves affected with mosaic disease, and peach leaves from trees affected with "yellows" and rosette were also examined and found to contain more oxidizing enzyms than normal green leaves. Although the chlorosis, or lack of chlorophyll, in all these cases was attended by an increase in oxidizing enzyms, it is evident from the above results with pineapples that the chlorosis of leaves is in some cases attended by a diminution of peroxidase.

In the light of the other work on the pineapple leaves it is probable that this deficiency of enzyms in the chlorotic leaves has no bearing on the chloresis, but is merely the result of the degeneration caused by the excess of lime and lack of iron in the plant.

\section{EFFECT OF LIGHT ON THE CHLOROSIS.}

It was observed in the field that plants growing under partial shade seemed less chlorotic than those exposed to full sunlight. To see if the chlorosis could be much diminished by partial shade a duplicate of experiment I (see p. 23) was run in a glass house that was heavily shaded.

The plants in the glass house showed very much less chlorosis than those exposed in the open. The results of this experiment are inconclusive, however, as the plants in the glass house did not make half the growth of those exposed in the open. Since the intensity of the chlorosis has been seen to be more or less dependent on the amount of growth, the smaller degree of chlorosis in this case was probably due to the fact that little growth was made.

It was found, however, that plants which had become strongly chlorotic and which had long ceased to grow, became decidedly greener when placed under heary shade for one or two weeks, but when they were again exposed to full sunlight they showed their original chlorosis within a few days.

The explanation of these facts is apparent. It has been shown that there is a continuous formation and destruction of chlorophyll in the plant. ${ }^{1}$ The destruction of the chlorophyll is brought about by strong sunlight and increases with the intensity of the light. In the chlorosis

1 H. Euler, Grundlagen und Ergebnisse der Pflanzenchemie, Braunschweig, 1908, pt. 1, p. 193. F. Czapek, Biochemie der Pflanzen, Jena, 1905, vol. I, pp. 452, 453, 468. H. Molisch, Ber. Deut. Bot. Gesell., 20 (1902), pp. 442-448. Molisch found that aloe leaves that became brown in direct sunlight became green again when placed in the shade.

[3ull. 11] 
of pineapples in calcareous soils the plant is unable to form the cllorophyll as fast as it is destroyed by the light. When the plant is partially shaded, however, the balance of the reaction is shifted; the chlorophyll is destroyed less rapidly, though it may be formed at the same rate as in the sunlight, so the plants become greener.

The appearance of less chlorotic plants in shaded portions of a field affected with chlorosis is, then, due to the fact that the plants have made a less rapid growth at the start than the rest of the plants, and also to the fact that the chlorophyll is destroyed less rapidly in the shaded plants.

\section{CONCLUSIONS FROM INVESTIGATIONS OF THE CHLOROSIS.}

In deciding as to what is the primary cause of the failure of pineapples on calcareous soils and of the appearance of the chlorosis, it should be borne in mind that chlorosis is not a specific disease, but is merely an outward manifestation that attends certain physiological disturbances in the plant. Plants suffering from poor drainage and from bacterial diseases and certain plants growing on calcareous soils all show chlorosis. It should also be taken into consideration that one disturbance in the physiology of the plant will bring on a series of other disturbances, which are to be regarded only as attendant phenomena.

In the above investigations it was found that pineapples, in common with some other plants showing chlorosis on calcareous soils, were greatly benefited by treatment with iron salts, the iron salts overcoming the chlorosis and inducing a normal growth.

No other treatment was found that overcame the chlorosis. It appears, then, that the plants need iron and that they are unable to obtain this from the soil, although there is a large percentage of iron in some of the calcareous soils. The facts that solutions of ferrous sulphate applied to the soil gave no result, while crystals applied to the roots or solutions of iron applied to the vegetative portions of the plant gave marked improvement as soon as they were absorbed, show that the carbonate of lime in the soil reacts with the iron (forming ferric carbonate) and depresses the availability of the iron for the pineapple plant. That all species of plants growing on calcareous soils do not suffer to an equal degree for lack of iron is probably because of their different abilities to take up iron. That certain species of plants differ in their ability to take up phosphoric acid is well known.

The ash analyses support in a general way the assumption that there is a lack of iron in the chlorotic plants and show that probably the increased absorption of lime creates a necessity for an increased quantity of iron. The excessive amount of lime in the plant may render inactive the small quantity of iron absorbed. ${ }^{1}$ With our pres- 
ent knowledge of the mineral nutrition of plants such an assumption is, of course, only speculative.

The facts that neither a merely alkaline soil nor a soil containing much assimilable lime induces chlorosis, but that a soil which is at the same time alkaline and contains much easily available lime (as a calcareous soil) does induce chlorosis, lend credence to the above view. In a soil alkaline with sodium carbonate there would be a depression in the availability of the iron, but not an increased absorption of lime. Plants grown on a soil containing gypsum absorb an increased amount of lime, but there is no depression of the availability of the iron on such soils. Plants grown on a soil containing calcium carbonate, however, absorb an unusual amount of lime, and because of the depression of the availability of the iron absorb but a small amount of iron.

That chlorotic plants contain less nitrogen and less peroxidase than green plants is probably because the nutrition has been disturbed by the increase of lime and lack of iron. The lower content of nitrogen and of the oxidizing enzyms are, then, not primary causes of the chlorosis, but rather results of the degeneration produced by the lack of iron. This view is strongly confirmed in the preceding work by the fact that treatment of chlorotic plants with iron increased the nitrogen and peroxidase content.

Although but little attention has been paid to the iron requirements of plants, Molisch ${ }^{1}$ has shown that iron exists in all plant organs, mostly in organic combination, and that seeds contain iron stored up in the globoid bodies of the aleurone grains. While iron is not a constituent of chlorophyll, it seems to be necessary for the formation of chlorophyll, since plants grown in iron-free solutions become chlorotic.

It seems, then, that pineapples growing on calcareous soils absorb an excessive amount of lime and an insufficient amount of iron; that as a result there is an inability to form chlorophyll and degeneration of the plant follows, as is shown by a decrease in the content of peroxidase, nitrogen, and occasionally potash.

\section{SUMMARY.}

Pot experiments and a chemical survey of the pineapple soils of Porto Rico show that the failure of pineapples, with the appearance of chlorosis, on certain areas is due to an excessive amount of carbonate of lime in the soil.

For ordinary sandy soils about 2 per cent of calcium carbonate renders them unsuitable for pineapples; smaller amounts than this do not appear to be injurious.

Soils composed principally of organic matter may contain about 40 per cent of calcium carbonate and still produce vigorous plants.

1 H. Molisch. Die Pflanze in ihren Beziehungen zum Eisen. Jena, 1892. 
Pineapple plantings on calcareous soils should be abandoned and the land planted to lime-loving crops.

In curing the chlorosis, fertilizers were ineffective, but treatment of the leaves with solutions of iron salts or crystals of ferrous sulphate applied to the roots was effective and induced a normal growth. This treatment does not appear to be commercially feasible.

The chlorosis is not caused by an organic disease, but is the result of a disturbance in the mineral nutrition of the plant induced by the calcareous character of the soil.

It is neither the mere alkalinity of calcareous soils nor the large amount of assimilable lime that causes this disturbance, but the combined action of the two properties.

The disturbance in the mineral nutrition of the plant, or the primary cause of the chlorosis, seems to be the lack of iron in the ash or the small amount of iron in the presence of a large amount of lime. $\Lambda$ mere high percentage of lime in the ash does not induce chlorosis.

Chlorotic leaves are lower in nitrogen and oxidizing enzyms than green leaves, due, probably, to the degeneration induced by the lack of iron.

Strong light increases the chlorosis by the more rapid destruction of the chlorophyll.

\section{ACKNOWLEDGMENT.}

The greater part of the analytical work detailed in this bulletin was performed by Mr. W. C. Taylor.

Thanks are due to various planters who kindly sent soil and plants necessary for the work, and to Mr. Lucas Valdivieso for 15 tons of limestone used in the experiments.

[Bull. 11] 




LIBRARY OF CONGRESS 